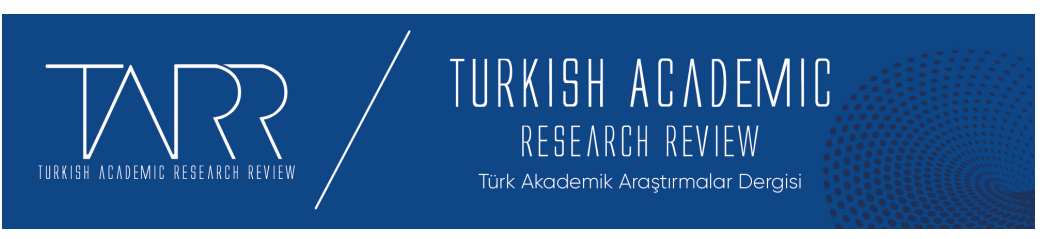

e-ISSN: 2602-2923 Yil/Year: 2021 Cilt/Volume: 6 Sayı/Issue: 2

\title{
Osmanlı Toplumunda Tütün Bağımlılığına Karşı Bir Sosyal Sorumluluk Örneği: Risâle Fi'd-Duhân
}

An Example Of Social Responsibility Against Tobacco Addiction In Ottoman Society: Rısāla Fī Al-Dukhān

\section{Ömer Faruk TEBER - Muzaffer TAN}

Prof. Dr., Akdeniz Üniversitesi İlahiyat Fakültesi İslam Mezhepleri Tarihi Anabilim Dalı. omerfarukteber@akdeniz.edu.tr, Orcid ID: 0000-0002-3126-3802

Doç. Dr., Ankara Üniversitesi İlahiyat Fakültesi İslam Mezhepleri Tarihi Anabilim Dalı. tanmuzaffer@yahoo.com, Orcid ID: 0000-0001-6969-0618

\begin{tabular}{r|l} 
Makale Bilgisi & Article Information \\
Makale Türü - Article Type & Araştırma Makalesi / Research Article \\
Geliş Tarihi - Date Received & 6 Mayıs / May 2021 \\
Kabul Tarihi - Date Accepted & 23 Haziran / June 2021 \\
Yayın Tarihi - Date Published & 25 Haziran / June 2021 \\
Yayın Sezonu & Nisan - Mayıs- Haziran \\
Pub Date Season & April - May - June
\end{tabular}

Atıf / Cite as: Teber, Ö. F.-Tan, M. (2021). Osmanlı Toplumunda Tütün Bağımlılığına Karşı Bir Sosyal Sorumluluk Örneği: Risâle Fi’d-Duhân/An Example Of Social Responsibility Against Tobacco Addiction In Ottoman Society: Risāla Fī Al-Dukhān. Turkish Academic Research Review, 6 (2), 449-476. Retrieved from https://dergipark.org.tr/tr/pub/tarr/issue/62824/933994

Intihal / Plagiarism: Bu makale, en az iki hakem tarafindan incelenmiş ve intihal içermediği teyit edilmiştir. / This article has been reviewed by at least two referees and confirmed to include no plagiarism. https://dergipark.org.tr/tr/pub/tarr

Copyright (C) Published by Mehmet ŞAHIN Since 2016- Akdeniz University, Faculty of Theology, Antalya, 07058 Turkey. All rights reserved.

Turkish Academic Research Review - Türk Akademik Araştırmalar Dergisi 


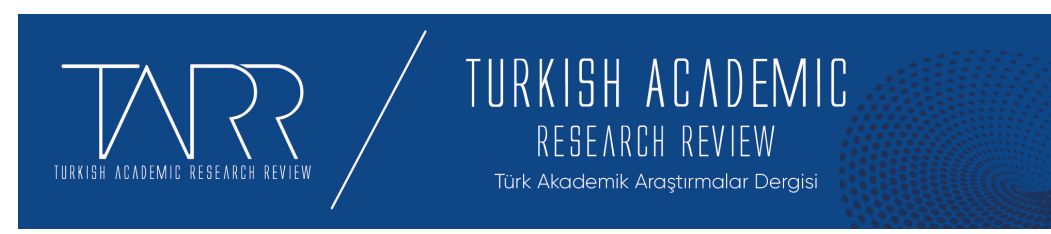

e-ISSN: 2602-2923 Yll/Year: 2021 Cilt/Volume: 6 Sayı/Issue: 2

\title{
Osmanlı Toplumunda Tütün Bağımlılığına Karşı Bir Sosyal Sorumluluk Örneği: Risâle Fi'd-Duhân
}

\author{
Ömer Faruk TEBER - Muzaffer TAN
}

\section{$\ddot{O} \mathbf{z}$}

Osmanlı Devleti'nde özellikle XVI. yüzyıldan itibaren daha sık görülmeye başlanan birtakım telif, şerh ve haşiye türü çalışmaların yoğun olarak tedhîn, kahve, mekûlat ve meşrûbât gibi konuları ele aldıkları görülür. Risâle fî Hakk-1 Kahve; Risâle fî Hakk-1 Duhân, Risale-i Duhân ve'l-Kahve gibi adlarla kaleme alınan tütün ve kahve konularına dair eserler, yazıldıkları dönemlerde çokça tartışılmış, kendi döneminden izler taşıyan bir sosyal tarih metni hüviyetini almışlardır. Bu tür risâlelerde sosyal sorumluluk taşıdıklarını düşünen ilim çevrelerinden kimseler, toplumsal duyarlılık gereği olduğunu düşündüğümüz bir faaliyet sunmuşlardır. Tütünün dinî ve şerî hükmünün genellikle alanda yazılmış fikıh müdevvenatına müracaat ederek mevzu bahis edildiği bu risale, Ankara Milli Kütüphane Yazma Eserler Bölümünde 3865 kayıt ve 297.544 tasnif numarasıyla tescil edilmiş kırmızı meşin bir cilt içerisinde Nesih kırması bir yazı ile telif edilmiştir. 1b-12b arasında tahrir edilmiştir. Bu risâlede ayrıca nargile, enfiye, afyon ve sekre sebep olan içereceklerden de sıkça söz edilmiş ve günaha iten kötü alışkanlıklar olarak bahsedilmiştir. Risalenin dibacesinde müellif kaydına rastlanmadığı gibi hatimesinde de müstensih kaydı ve tarihi yer almamaktadır. Türkiye kütüphanelerinde yazma koleksiyonlarında pek çok örneği mevcut bu tür risâleler, genellikle tütün, kahve, çay ve teskin edici maddelerin kullanımı ile ilgili açıklayıcı ve bağımlılığına karşı toplumu aydınlatıcı bir muhtevaya sahiptirler. Risalelerde çoğunlukla müellif kaydına rastlanmayan ve anonim olan bu eserler, genel itibarı ile tütünü, kahveyi ve bu gibi müsekkinata bağımlılık hakkında haram, mekrūh ve mübah olduğunu çeşitli fikhî deliller ile ikna yoluna gidildiği görülmektedir. Risâlelerin pek çoğu tütünü olumsuz göstermeye ve kötülemeye ayrılmıştır. Bununla birlikte Kahve ve tütün mamullerinin İslâm ülkelerine ve Osmanlı toplumunun yaşadığı coğrafyalara girmesinden sonra ortaya çıkan, bu maddeyi kullanmanın hükmüyle alakalı tartışmalar fikhi araştırmalara ve reel hayat içerisindeki problemlerin çözümüne yönelik bir canlılık getirmiştir.

Anahtar Kelimeler: Bağımlılık, Osmanlı Toplumu, Tütün, Duhân, Yazma

\section{An Example Of Social Responsibility Against Tobacco Addiction In Ottoman Society: Risāla Fī Al-Dukhān}

\begin{abstract}
It is seen that in the Ottoman Empire, some works, including sharh and hashiya works, composed from the sixteenth century onward began to focus, in a more formalistic approach, mostly on such issues as tadkhîn (smoking), coffee, foods and beverages. The works on tobacco and coffee mostly written with names such as Risāla fì Haqq Qahwa; Risāla fì Haqq Dukhān, Risāla-yi Dukhān wa al-Qahwa were widely discussed in the period they were written, and thus they are, in a sense, social history texts bearing traces of their own period. In such treatises, socially responsible scholars presented an activity that can be regard as social sensitivity and responsibility. This article deals with such an anonymous treatise Risāla fi al$d u k h \bar{a} n$. In the treatise in which the religious provisions of tobacco are discussed by
\end{abstract}

Turkish Academic Research Review - Türk Akademik Araştırmalar Dergisi 
referring generally to the fiqh works written in the field has been copied with a Naskh-broken script in a red leather binding registered with 3865 registration and 297.544 classification number in the Department of Manuscripts of the Ankara National Library. The treatise has been edited between $1 \mathrm{v}-12 \mathrm{v}$ folios. In the treatise, hookah, snuff, opium and the drinks that cause drunkenness are frequently mentioned, and regarded as bad habits that lead to sin. Neither the author's record is found in the preamble of the treatise, nor the record and date of the copyist in the epilogue.

Keywords: Addiction, Ottoman Society, Tobacco, Dukhān, Manuscript

\section{Structured Abstract}

It is seen that in the Ottoman Empire, some works, including sharh and hashiya works, composed from the sixteenth century onward began to focus, in a more formalistic approach, mostly on such issues as tadkhîn (smoking), coffee, foods and beverages. The works on tobacco and coffee mostly written with names such as Risāla fì Haqq Qahwa; Risāla fì Haqq Dukhān, Risāla-yi Dukhān wa al-Qahwa were widely discussed in the period they were written, and thus they are, in a sense, social history texts bearing traces of their own period. In such treatises, socially responsible scholars presented an activity that can be regard as social sensitivity and responsibility. This article deals with such an anonymous treatise Risāla fi al$d u k h \bar{a} n$. In the treatise in which the religious provisions of tobacco are discussed by referring generally to the fiqh works written in the field has been copied with a Naskh-broken script in a red leather binding registered with 3865 registration and 297.544 classification number in the Department of Manuscripts of the Ankara National Library. The treatise has been edited between $1 v-12 v$ folios. In the treatise, hookah, snuff, opium and the drinks that cause drunkenness are frequently mentioned, and regarded as bad habits that lead to sin. Neither the author's record is found in the preamble of the treatise, nor the record and date of the copyist in the epilogue. Such treatises, of which there are many examples in manuscript collections in Turkish libraries, generally have a content that explains the use of tobacco, coffee, tea and sedatives and enlightens the society against addiction. In these works, which are mostly have no record of the author and anonymous, it is seen that it is generally tried to prove with various legal evidences that addiction to tobacco, coffee and similar sedatives is harām, makrūh and mubāh. Most of the treatises are allocated to demonizing and vilifying tobacco. However, the discussions about the judgement of using this substance, which emerged after the entry of coffee and tobacco products into Islamic countries and the geographies where the Ottoman society lived, brought vitality to legal researches and the solution of problems in real life.

It is seen that tobacco and tobacco products are one of the various pleasure-giving substances that the society has begun to recognize in the Ottoman Empire since the sixteenth century. Many separate works were composed at that time about tobacco and its harms, which was called tadkhīn, dukhān and tadkhīnāt. The brief pamphlets in the manuscript collections of the Turkish Libraries on this subject show us that the subject was dealt with in terms of legal and social aspects. Considering the abundance of the works on this subject, we witness that poetical and prosaic literatüre, and various fatwa books on pleasure-giving substances such as tobacco, coffee and opium were written. In the context of these discussions, many monographic works have been written since the eighteenth century. It has even been seen that commentaries (sharh) and annotations (häshiya) were written on some of them and the subject were discussed in various scholarly sessions. 
In this study, we will share an anonymous dukhān treatise on drug addiction or on pleasure-giving substances, which the Ottoman Empire struggled with, especially in the last two centuries. Dukhān addiction was handled legally, and it was emphasized that dukhān has a content that can lead people to other illicit addictions such as alcohol. As can be clearly seen from this treatise, the scholars who tried to enlighten the society saw the next stage of dukhān addiction as the beginning of alcohol addiction and undertook the task of warning people against sedative substances. On the other hand, in the treatise, besides the material losses caused by the addiction to dukhān, it is emphasized that it is a bad habit that deteriorates health, wastes human energy, weakens the will, even destroys the will, and distracts the person from his family, environment, and basic human and religious duties. The behavioral model that the treatise aims to convey to the reader in the final analysis is to give the individual the understanding that he goes through an education process throughout his life, since the individual will be asked to account for all kinds of blessings in the world, such as his life, time, health and leisure time. We should emphasize that what is at issue here is not only behavioral disorders that we think are the source of the negativities in human behavior, but also substance addiction caused by environmental conditions.

The work called Risāla fì al-Dukhān has been written as three main chapters. In the first chapter, there are a total of twenty "kalām", each of which is written as a title declaring a separate legal opinion of the author. In this chapter, the views of the ulama that tobacco and tobacco manufacturing are illicit (harām) are mentioend, and sometimes exaggerated inferences are used to cause avoidance.

The second chapter, in the words of the author, "declares dukhann's pains and afflictions, its diseases and damages". In this part, the harms of tadkhīn, opium and other smoking substances are tried to be explained under the headings. In this chapter, there are forty-three articles in total, and each of them deals with different subjects. For example, dukhān is regarded as a sign of hypocrisy because it is called with imported names such as, cigar and cigarette.

The third chapter, on the other hand, has been written as twenty articles to point out the financial and moral gains of those who left dukhān and repented.

\section{Giriş}

Müspet ilimlerde bağımlılık kavramının XX. Yüzyılın ortalarından itibaren literatüre girdiği görülmektedir. Bu kavramsallaştırmaya göre bağımlllık, bağımlı kişinin bağımlısı olduğu madde veya davranışın diğer davranışları karşısında çok büyük üstünlük kazanması sonucu psikolojik, davranışsal ve zihinsel sorunların yaşandığı vakalar olarak tarif edilmişlerdir ${ }^{1}$. Bağımlılık kavramıyla, yardım ve güvenlik için bir başkasına dayanma durumu ifade edilmektedir. Bağımlı kişi denildiğinde de başkalarına boyun egen, edilgen, pasif ve daima bir başkasının arkasına sığınan, bireysel özgürlüğü ve seçimleri olmayan şahıslar kastedilmektedir. Bağımlılık, kişinin hayatını kendi iradesi ile sürdürme ve yönlendirme özgürlüğünü

1 Orhan Gürsu, Bağımlılık ve Din Nöropsikolojik Bir Yaklaşım, Dem Yay., İstanbul 2018, s.29.

Turkish Academic Research Review - Türk Akademik Araştırmalar Dergisi 
452 Osmanlı Toplumunda Tütün Bağımlılığına Karşı Bir Sosyal Sorumluluk Örneği: Risâle Fi'd-Duhân

kaybederek başka şeylere bağımlı hale gelmesidir. İnsanlar sigaraya, uyuşturucu ve uyarıcılara, elektronik ve sanal hayata, kumara, paraya, cinselliğe ve başka insanlara bağımlı olabilmektedirler. ${ }^{2}$

Günümüz toplumları, modernleşme, sanayileşme, teknolojik gelişme ve değişmelerin hızlı bir şekilde gerçekleştiği bir dönemi yaşarlarken aynı zamanda işsizlik, değerlerdeki aşınma, aile sorunları, ekonomik problemler, sosyal destek yoksunluğu, güvensizlik ve ahlaki yozlaşma gibi problemleri de yine aynı hızla yaşamaktadır ${ }^{3}$. Bu problemlerle karşı karşıya kalan bireyler farklı arayışlara yönelebilmektedirler ${ }^{4}$. Hızlı değişen ve gelişen günümüz dünyasında bağımlılığın, her geçen gün artan, sadece bireyi değil toplumun her kesimini etkileyen büyük ve önemli bir problem haline geldiği görülmektedir. ${ }^{5} \mathrm{Bu}$ problem farklı disiplinlerde pek çok araştırmacı tarafından ele alınmış ve alınmaya devam edecektir. Çalışmaya konu edilen risale de kendi döneminde söz konusu problemi ele alan bir çalışma olarak değerlendirilebilir.

İlahiyat alanında ise bağımlılık, dinî ve ahlâkî menhiyatı da kapsayacak şekilde insanı dünya ve ahiret huzurundan mahrum etmeye yönelik kötü alışkanlıklar olarak dinin temel kaynaklarında kendisine kolayca yer bulmuştur. Kur'ân-1 Kerîm ve Sünnet-i nebevî insan doğasında mevcut bulunan menfi temayüllü nefse karşı, kendi nefsini sürekli kınayarak ${ }^{6}$ daima tazarru ve niyaz makamında durmasını önermektedir. Kur'ân'ın ana teması, Allah’ı çokça tezekkür etmenin ancak insana huzuru kazandıracağını vurgulamaktadır ${ }^{7}$. Bunun yanı sıra insanın hassas bir psikolojik yapıya sahip olması fizyolojik ve psikolojik bağımlılıklarının bulunması da hayatını yaratıcının emir ve tavsiyelerine göre tanzim etmeye çalışan Müslüman şahsiyet için önemli nefsâni hevesâta iten faktörler olarak zikredilmektedir. Nefsânî arzulara, (özellikle) kadınlara, oğullara, yığıın yı̆̆ın biriktirilmiş altın ve gümüşe, soylu atlara, sağmal hayvanlara ve ekinlere düşkünlük insanlara çekici kılınmıştır. İşte bunlar dünya hayatının geçici menfaatleridir.

2 Musa Tosun, "Bağımlılık ve Arka Planında Yer Alan Sebepler", Sosval Hizmet ve Bütün Yönleriyle Bă̆ımlılık, Edit. Y. Sinan Zavalsız, Grafiker yayınları, Ankara 2020 s. 13.

3 Ali Albayrak, "Alevi-Bektaşi Ritüelleri ve Temel Kurumlarından Hareketle Sosyal Bütünleşme”, Sûfi Araştırmaları Sufi Studies, 2015, C. VI, S. 12, s. 23.

4 Atay, Rıfat - Ciğer, Mustafa, "Bilișsel Gelișim Seviyelerine Göre İnsanın Allah'la İletişimi”, I. Uluslararası Din ve İnsan Sempozyumu "Din, Dil ve İletişim” 10-12 Ekim 2019 Eskişehir, 2019, s. 996.

5 Vehbi Ünal, "Sosyal Bir Sorun Olarak alkol/Madde Ve Teknoloji/Dijital Bağımlılığı", Sosyal Sorunlarda Güncel Tartışmalar, Edt. Y1lmaz Dașlı, Ankara 2019, s. 269.

${ }^{6}$ Nefs terbiyesini sistematik olarak ele alan tasavvuf ilmidir. Sûfî çevrelerde "kınayanın kınamasından korkmamak esası üzerine bina edilen "Melâmet" anlayıșı ortaya çıkmıștır. Bkz. Ömer Dilmen, Turuk-ı Aliyyede Cihâz-ı Tarîkat, İlahiyat Yayınları, Ankara 2020, s. 41-

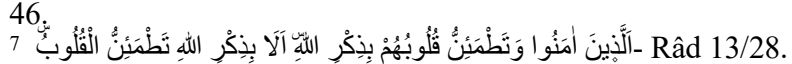


Hâlbuki varılacak güzel yer, Allah'ın katındadır diye buyurarak insanı günaha götüren harici sebepler içinde dünya hayatının cazibesi anlatılarak insanın manevi olarak terakki etmesi; dünya ve ahiret hayatında mutlu olmasının yolları gösterilmiştir ${ }^{8}$. İnsanın zayıf bir tabiatta yaratıldığı da tespit edilebilen bir gerçeklik olarak dururken ayrıca insanın mânevî yücelişine karşı mücadele etmeye ahdetmiş olan şeytanın tahriklerinin de âdemoğluna ahirette elde edeceği nimetlere karşı dünya hayatının geçici zevklerini önererek onu doğru yolundan saptırmaya çalıştığı ifade edilmektedir. Buna mukabil insanı en mükemmel şekilde yaratan Allah Teâlâ kulunun kötü alışkanlıklarından ve bağımlılıklarından kurtulmasına ve insani değerlere bağlı kalarak ömrünü ebedî mutluluğuna vesile yapmak istemektedir ${ }^{10}$. İnsanın Allah'a kulluğu ne kadar samimi ve içten olursa hem nefsani arzularının ve hem de fizyolojisinin başka varlıklara olan bağımlılığından da kurtulabilme imkânına sahip olabileceği dini literatürde dile getirilmiştir ${ }^{11}$. Burada söz konusu olan yalnızca insan davranışlarında yaşamış olduğu olumsuzluklara kaynaklık ettiğini düşündüğümüz davranış bozuklukları değil aynı zamanda çevre koşullarının içerisine çektiği madde bağımlılığı olduğunu da söylemeliyiz.

Kahve ve tütün mamullerinin İslâm ülkelerine ve Osmanlı toplumunun yaşadı ̆̆ı coğrafyalara girmesinden sonra ortaya çıkan, bu maddeyi kullanmanın hükmüyle alakalı tartışmalar fikhi araştırmalara ve reel hayat içerisindeki problemlerin çözümüne yönelik bir canlılık getirmiştir. Bu tartışmalar bağlamında XVIII. Yüzyıldan itibaren birçok monografik çalışma kaleme alınmıştır. Hatta bir kısmına şerh ve haşiye yazıldığı da görülmüş, konu çeşitli ilim toplantılarında mevzu bahis yapılmışıır' ${ }^{12}$.

Bu çalışmamızda Osmanlı Devleti'nin özellikle son iki asırda mücadele vermek zorunda olduğunu düşündüğü madde bağımlılı̆̆ı veya mükeyyefât olarak nitelenen maddeler konusunda yazılmış anonim bir duhân risalesini transliterasyonunu da yaparak asıl metnini paylaşacağız. Duhân bağımlılı̆̆ı fikhî bir çerçevede ele alınmış, duhânın kişiyi haram olan alkol gibi başka bağımlılıklara sürükleyebilecek bir muhtevaya sahip olduğu üzerinde durulmuştur. Toplumu

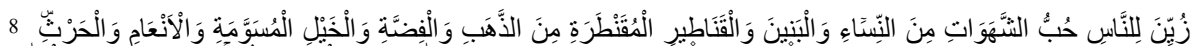

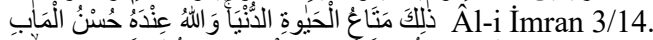

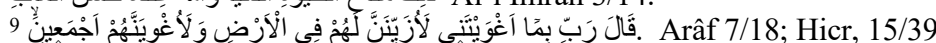

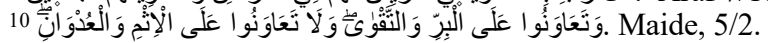

11 Orhan Gürsu, "İnancın Bağımll11k Karșssindaki Fonksiyonu", Sosval Hizmet ve Bütün Yönleriyle Bağımllılk, Ed. Y. Sinan Zavalsız, Grafiker Yay., Ankara 2020, s.289.

12 Kâşif Hamdi Okur, "17. Yüzyıl Osmanlı Fıkıhçılarının Nevazile Yönelik Fıkhî Argümantasyonu (Mehmet Fıkhî el-Aynî ve Risâletu'd-Duhân ve'l-Kahve Örneği)", Sahn-ı Semân'dan Dârulfünûn'a Osmanlı'da İlim ve Fikir Dünyası (Âlimler, Müesseseler ve Fikrî Eserler) - XVII.Yüzyll, 2017, s. 381.

Turkish Academic Research Review - Türk Akademik Araştırmalar Dergisi 
aydınlatmaya çalışan ulemâ ve fuzelâ bu risaleden de açıkça görüleceği üzere Duhân bağımlılığının bir sonraki aşamasının da alkol bağımlılığı başlangıcı niteliğinde görmüş ve insanı müsekkin edici maddelere karşı uyarma görevini üstlenmiştir. Öte yandan risalede duhân bağımlılığının yol açtığı maddî kayıpların yanı sıra sıhhatı bozan insan enerjisini boşa harcayan, iradeyi zayıflatan, hatta âdeta yok eden ve kişiyi ailesinden, çevresinden, temel insanî ve dinî görevlerinden çekip uzaklaştıran kötü bir alışkanlık olduğu üzerinde durulmuştur ${ }^{13}$. Risalenin son tahlilde okuyanı ulaştırmayı amaçladığı davranış modeli, bireye verilen dünyadaki hayatı, zamanı, sıhhat ve boş zamanı gibi her türlü nimetin hesabının en ince ayrıntısına kadar sorulacak olmasından dolayı insanın ömrü boyunca bir eğitim sürecinden geçtiği anlayışını kazandırmak olmuştur.

Türkiye kütüphanelerinde yazma koleksiyonlarında pek çok örneği mevcut bu tür risâleler, genellikle tütün, kahve, çay ve teskin edici maddelerin kullanımı ile ilgili açıklayıcı ve bağımlılığına karşı toplumu aydınlatıcı bir muhtevaya sahiptirler. Risalelerde çoğunlukla müellif kaydına rastlanmayan ve anonim olan bu eserler, genel itibarı ile tütünü, kahveyi ve bu gibi müsekkinata bağımlılık hakkında haram, mekrūh ve mübah olduğunu çeşitli fikhî deliller ile ikna yoluna gidildiği görülmektedir. Risâlelerin pek çoğu tütünü olumsuz göstermeye ve kötülemeye ayrılmıştır. Duhana olumsuz bakan risâle müelliflerinin bir kısmı tütüne doğrudan haram demekte; diğer bir kısmı da tütünü kötü görmekle birlikte, doğrudan yasaklayan bir nașṣ bulamadıkları için mekrūh hükmünü vermekle iktifa etmektedirler. Tütünü kötüleyen risâlelerde tütün hakkında genelde isrāf, abes, habīs, sarhoş edici, bidat, zararlı, eziyet verici, kötülüklere sebep olan gibi suçlamalar yapılmış ve bu genel hükümler âyet ve hadislerle temellendirilmeye çalış1lmıştır ${ }^{14}$. Hükmü naslarda açıkça ifade edilmeyen, önceki müçtehitlerin içtihatlarında yer almayan tütün kullanımı meselesi, nevazil niteliğinde bir mesele olarak XVII. yüzyıldan itibaren yoğun bir şekilde tartışılmaya başlamıştır ${ }^{15}$. Bu

\footnotetext{
13 Osmanlı ilim çevreleri genellikle tütünün sarhoşluk verme (sekr), selim tabiatlı kimselerin hoşlanmadığı kötü bir şey olma, selim akıl ve tabiat sahipleri tarafından nefret edilme (fahş), kötü kokusu bulunma (eza) ve gereksiz harcamaya yol açma (seraf) şeklinde beş delil ile haram olduğunu ortaya koymaya çalışmıştır. Bkz. Osman Şahin, "Risâle fî Hükmi'tTütün ve'l-Kahve li-Muhammed Fikhî el-Aynî el-Hanefî̀ Emînü'l-Fetvâ (Dirâse ve Tahkîk)", İslam Hukuku Araştırmaları Dergisi, 2018, sayı: 31, s. 697.

14 Mehmet Kalayc1, Eyüp Öztürk, "18. Yüzyıl Osmanlı Coğrafyasında Tütünün SosyoKültürel Zeminine Dair Bir Metin: Ebū Sehl Nu'mān Efendî ve Tahlîlu'd-Duhân Adlı Risâlesi”, Ankara Üniversitesi İlahiyat Fakültesi Dergisi 58/1, (2017), s.13.

15 Tütün, kahve ve çeșitli maddelerin helal mi yoksa haram mı olduğuna dair İslam fikıhçıları arasındaki tartışmalar sadece dar bir bölgede yapılan tartışmalar olmayıp bütün İslam coğrafyasındaki ulema arasında yapılan ve sonuçlan itibariyle geniş kitleleri ilgilendiren popüler nitelikli tartışımalar olmuştur. Bkz. Nurettin Ceviz,
} 
bağlamda tütün kullanmayı haram, mekruh veya mubah kabul edenler bulunmakla birlikte, asıl tartışma haram ve mubah kabul edenler arasında cereyan etmiştir. ${ }^{16}$

Osmanlı toplumuna kanaat önderliği yapan Bahaî Mehmet Efendi $(\text { ö.1064/1654) })^{17}$ gibi alimler tütüne mubah diyerek savunurken ${ }^{18}$; Altıparmak Mehmet Efendi (ö.1033/1623) ${ }^{19}$ ve Nablûsî Abdulgani b. İsmail (ö.1143/1731) $)^{20}$ gibi kimi sufi meşrep şahıslar, dervişlerin semâ yapmaları ve mûsiki aleti kullanmalarının cevazına ve tütün içmenin mubah olduğuna dair görüşlere sahiptir ${ }^{21}$. Ayrıca tütünün haram olduğunu savunan Haskefî (ö.1088/1677)22, Atâullah Mehmed Efendi (ö.1127/1715) 23 ve Ebû Said el-Hadîmî (ö.1176/1762) ${ }^{24}$ gibi alimler de tütünün tahrimen mekruh olduğunu iddia etmişlerdir ${ }^{25}$. Konuyla ilgilenen müelliflerin ilmî seviyeleri ile ilgili tartışmalar bir yana bırakılacak olursa öncelikle, içtihat makamında bir kişinin bulunmadığının ve daha evvelki müctehidlerin görüşlerinin taklit edilmesinin savunulduğu bir dönemde hakkında âyet, hadis veya seleften bir görüşün mevcut olmadığı bir hususta ilmi çevrelerde duhan, kahve ve çay gibi madde bağımlılıkları ile ilgili tartışmalar yapıldığı görülmektedir. Bundan başka hangi delil ve yöntemle nasıl hüküm verileceği konusunu tartışmak ve ardından tütün ve bu gibi maddelerin kullanımının dinî hükmüne dair görüşlerini devrin âlimlerinin fikhın geleneksel metodolojisi ve kavramları çerçevesinde delillendirmek durumunda kaldıkları görülmektedir ${ }^{26}$. İslâm dininde haram kılınan

"Kahvenin İslâm Dünyasına Girişi ve Arap Edebiyatında Ele Alınışı", EKEV Akademi Dergisi - Sosyal Bilimler -, 2004, cilt: VIII, say1: 18, s. 347.

16 Kâşif Hamdi Okur, "17. Yüzyıl Osmanlı Fıkıhçılarının Nevazile Yönelik Fıkhî Fıkhî Argümantasyonu", s. 381.

17 Mehmet İpşirli, Mustafa İsmet Uzun, "Bahaî Mehmet Efendi”, DİA., İstanbul 1991, C.4/463-465.

18 Duhân ve tedhînin şer'an mubahlığını savunanların genellikle, tütünün faydalı ve bazı hastalıkları tedavi edici olduğu, eşyada asıl olanın da mubah olması gerektiği anlayışından hareketle tütün mamullerinin haram veya mekruh olduğunu söyleyenlerin iddialarını çürütmeye çalıştıklarını tespit ediyoruz.

${ }_{19}$ Adnan Karaismailoğlu, “Altıparmak Mehmed Efendi”, DİA., İstanbul 1989, C.II/542.

${ }^{20}$ Ahmet Özel, "Nablusî Abdulgani b. İsmail”, DIA., İstanbul 2006, C.32/268-270.

${ }^{21}$ XVII. yüzyılda yaşamış Osmanlı müderrislerinden olan Ahmed Devletî Efendi de, tedhine dair yazdığı bir risâlesinde, tütün ve mamullerinin kullanımının mubah olduğunu ve onların şer'an ve tab'an necis olmadığını ortaya koymaya çalışmıştır. Bkz. Şenol Saylan, "17. Yüzyıl Osmanlısında Bir Tütün Müdafaası: Ahmed Devletî̀nin Risâletü'l-İnsâniyye fî̀ Bahsi'dDuhâniyye, Adlı Risâlesi”, Abant İzzet Baysal Üniversitesi İlahiyat Fakültesi Dergisi [Dergiabant: Abant İzzet Baysal Üniversitesi İlahiyat Fakültesi Dergisi], 2020, C. VIII, Say1. 1, s. $27-57$.

${ }_{22}$ Ahmet Özel, "Haskefi”, DİA., İstanbul 1997, C.16/387.

${ }^{23}$ Mehmet İpşirli, “Atâullah Mehmed Efendi”, DİA., İstanbul 1991, C.IV/46.

${ }^{24}$ Mustafa Yayla, "Hadimî Ebû Said", DİA., İstanbul 1997, C.15/24-26.

25 Tütün konusunda Osmanlı Toplumu içinde yazılan risaleler için bkz. Abdullah Kavalcığlu, "Sûfilerin Güncel Fikhî Tartışmalara Bakışı: Ankaravî'nin Tütün İçmenin Hükmünü Değerlendirişi”, Bülent Ecevit Üniversitesi Illahiyat Fakültesi Dergisi, 2020, cilt: VII, say1: 2, s. 611-634.

${ }^{26}$ Şükrü Özen, “Tütün”, DİA., İstanbul 2012, C.42/5.

Turkish Academic Research Review - Türk Akademik Araştırmalar Dergisi 
456 Osmanlı Toplumunda Tütün Bağımlılığına Karşı Bir Sosyal Sorumluluk Örneği: Risâle Fi'd-Duhân

maddeler, fesat, habîsat, israf, zarar vb. illetler üzerine bina edilmiş olduğu bilinmektedir. Alkollü içecekler aklın ve malın kaybına, kumar haksız kazanca, insanın enerjisini alarak onu yalnızlığa iten kötü alışkanlıklar ve genel ahlaka aykırı olan davranışlar yasaklanmıştır.

Transliterasyonunu sunduğumuz bu risalede müellif, tütün kullanmanın mubah olduğunu kesinlikle kabul etmez iken, Buna mukabil haram olduğunu ispata çalışmış ve bunu çeşitli gerekçelere dayandırmıştır. Bu gerekçelerin en başında da tütünün pis, selim tabiatlı kişilerin tiksindiği bir nesne olduğunu iddia etmiş, israf ve bidat gerekçelerini de ekleyerek insan ruhunu ve cesedini tiksindirici bir maddeyle zihni ve bedenini kirlettiğine kanaat getirmiştir. $\mathrm{Bu}$ bakış açısına göre tütün kullanmakta misvak vb. yöntemlerle ağzı ve dişleri temiz tutmayı amaçlayan sünnete açıkça bir muhalefet söz konusudur. Ayrıca kamu otoritesinin tütün kullanmayı yasaklaması da kimileri tarafından haramlık gerekçesi olarak kabul edilmiştir.

Mubahlığını savunanlar ise haram veya mekruh olduğunu söyleyenlerin iddialarını çürütmenin yanında; tütünün faydalı ve bazı hastalıkları tedavi edici olduğu, eşyada asıl olanın mubahlık olduğu, "Ümmetim hata üzerinde birleşmez" hadisinden hareketle toplumda çok fazla yaygınlık kazanmasını tütünün mubahlığında sükutî bir icma bulunduğu kanaatine ulaşmışlardır27. Bütün bu tartışmalar bir yana Risâle fî'd-Duhân adlı bu risâle ve buna benzer metinlerin bize gösterdiği, o günün şartlarında yapılan popüler nitelikli tartışmalara yönelik referanslardır. Osmanlı Devleti'nin son dönemlerinde yaşanan toplumsal sorunlara yönelik ulemanın fikhî ve mezhebî çözüm arayışları için birer nümûne olmalarıdır.

\section{Risâle fî’d-Duhân}

El-hamdu li-veliyyihî ve's-salâtu ve's-selâmu al'â nebiyyihi ve âlihî ecma'în.

Ma'lûm ola ki duhân yani tütün kâfirler tarafından zuhur etmiş, bin on senesi tarihinde Endülüs memleketinde sefihler içmesine başlayıp sonra İslâm

${ }^{27}$ Ayşegül Yılmaz, Kitap Tanıtımı/Review, “es-Sulh Beyne'l-İhvân fî Hükmi İbâhati'dDuhân, Abdülganî b. İsmâil en-Nablusî (tahkik: Muhammed Edîb el-Câdir), Dımaşk, 2015, 240 sayfa". Abant İzet Baysal Üniversitesi Illahiyat Fakültesi Dergisi, Bahar 2019, C.7, S:13, s.337-340. 
arasında şâyi' olup isti'mâlde iken dağlar gibi olan ol-zamânın ulemaları duhân mekruh ve bid'attir diyerek duhân hakkında çok büyük risâleler te'lîf etmişler ise de Arabî lisanıyla olduklarından ulemâlardan gayrı kimse manâların bilmeyip şimdiki ulemâların ekseri dünya muhabbeti dağına dalmış olmakla câhillere müdâhane ve dünya ehline ve fasıklara ve zâlimlere ihtlât edip ulemâlar dahi duhân isti'mâlde câhiller gibi olup duhân hakkında olan fenâ ve kabîh ve zarar ve mekruh ve harâm olmasını ve hükmünü câhillere söylemeyip beyan etmezler. Belki duhân içmek ile câhillerin duhânı içmelerine sebep olur, ulemâların bu câhillere müdâhane ve kahvehâne mahall-i rezâlette câhiller ile beraber oturmalarını ve fâsıklara ve zâlimlere karışmaları dinin fesadına sebep olur. Bu zamanda olduğu gibi ne'ûzu-billâh ulemâların böyle ve fest olmalarına câhiller sebep oldu. Zira avâmlara ve câhillere farzdır ki ulemaya ta'zîm ve ikrâm etmek lâkin câhiller nefislerine ve şeytana muvâfakat etmek ile gayet âsî ve fâsık olup ulemalar bunlara va'z-u nasihat edip günah ve fenâ şeylerden men' ve zecr ve nehyetmekte bu nasîhatlar nefislerine ağır ve acı olmakla ulemâlara buğz edip kaçmak muâmelesi göstermek ile ulemâlar, medâr-1 ma'îşette muztar kalıp insanlar arasında şöhret bulacağım diyerek câhillere muvâfakat etmeğe başlayıp sonra müdâhane ederek beraber olup nihayetinde ulemâlar, câhiller ve zâlimler ile beraber olup Haktan sükût edip fisklar ve ma'siyetler cok olu her memleketler ulemâsız kalmış gibi cehl-i dünyayı kaplamıştır. Ve böyle olması her kimsenin ma'lumudur. Bu duhân dahî her insan müptelâ ve musır olmakla her memleketlerde perîşân ve rezâlet-işkâr olmuştur. Kimsenin aklî idrâk etmez oldu. Ve duhânın aslı bir ma'siyet ise de gece gündüz içmesine musır olup deveâm üzere olmasıyla türlü haramlara ve belâlara sebep olarak günahların büyüklerinden olup isti'mâl eden kimseler fâsık olup tevbesî vacip iken tevbesiz nice insan âhirete gitmede haller âşikâre olmuş kimsenin aklî idrâk etmez. Emr böyle olduysa bu duhânın ahvâlini ve hükmünü beyân eden kitapların kelâmlarnı terceme eden avâmlara ve câhillere bildirmek şer'ân vacip olan şeylerden olmakla ve bu vaktin ulemalarının halleri bundan evvel ma'lûm olmuş. Ebedî bu sebepten bu âciz -i hakire gayret her insana fâidesi râci' olup duhânı terk ve tevbesine sebep olup iki cihanda insanlar selâmet bulsun içun Rabbimin rızasını tâlip olduğum halde terkî lisanıyla dağlar gibi olan ulemâların kelâmlarını beyân ederek duhân hakkında üç bab üzere bir risâle Rabbimin inayetiyle tertip ettim. Rabbim celle şânuhû'dan ricâ ederim ki; çok ihvânlar bunun ile irşâd olur. Bunun içun bu risâleye "Mürşidü’l İhvân fî Hakkı'd-Duhân" ad verdim. Ma'lûm ola ki; bu risâleyî okumak ve okutmak emr-i lâzımdır. Ve bir de dinlemesi ve amel etmesi şer'ân vacip olan şeylerdendir. Bu risâleyi memleketlere ve karyelere dağıtıp neşrî büyük sevâb olur. Zirâ insanların duhandan tevbelerine sebep olur. Zîrâ bu zamanın

Turkish Academic Research Review - Türk Akademik Araştırmalar Dergisi 
ulemaları duhân-ı isti'mâlde oldukları câhilleri duhândan men' ve nehyetmezler. Halbuki, men'i lâzımdır. Tütün içûn neşretmek büyük sevaptır. Ve dahî -2b- bu risaleyi kangi/hangi kimse alıp memleketlere neşredip insanların islahına sebep olursa Rabbimiz Celle Şânuhû bu kimseyi iki cihânda azîz eyleyip hayırlı murâtlar ile müşerref eyleye ve dahi ma'lûm ola ki bu duhânın bin on tarihinden sonra zuhur etmesi duhânın dahi akla fenâ ve kabîh olmasına delil ve şâhittir. Zîra ümmet fesâda gitmiş vakitte zuhur etmiş. Bunun gibi nice bid'atler ve harâmlar ve zulümler ve tuğyanlar zuhur etmiş bir zamanda ihdâs olan şeyin böyle insanlar isti'mâl ettikleri şey fenâ olmasına delil ve şâhittir. Ve dahi ihvân karındaşlara vasiyetim budur ki: $\mathrm{Bu}$ risâleyi red ve ta'arruz tarîkiyla bakmayalar; hüsn-i nazar ile bakıp kabul edip amel edeler. Ve sâir insanlara kabul ettirmeye sa'y ve himmet edeler. Böyle işleyenlere Rabbim Te'âlâ iki cihânda selâmet ihsân eyleye âmin. Ve dahi duhân içen insana rif'atle nasihat edip duhânın ahvâlini beyân edip tevbeye da'vet edeler. Kabul ederler ise fe-bihâ. Kabul etmezlerse kalp ile buğz etmeli. Ve dahi duhân hakkında bu kelâmları buyurân ulamâların meşhurlarını beyân: eş-Şeyhu'l-âlim ettahrîr ve'l-kâmilu'l-kebîr Mevlânâ Sa'îd Muhammed el-Hâdimî, ve şârihu'l-Hâdimî İsmâ'îl b. Osmân, ve'l-âmilu'l-Fâzıl Muhammed Recep, ve'l-Fâzılu't-Tahrîr eşŞeyh Ahmed er-Rûmî fî̀ Mecâlisihî. Ve'l-Fâzılu'l-Müdekkik zü'l-Cenâheyn İsmâ'il Hakkı, ve'l-Fâzıl el-Akdâğî ve'l-kâmilu'l-âlim İsmâ'îl Niyazî rahimehumullah.

Bunların tafsilini talep eden arabî olarak “Tuhfetu'l-İhvân fî Hakkı'dDuhân" risâlemize nazar etsin. Zirâ ona nazar eden kimse kâni’ olur. Evvelki bâb, duhânın mezmûmiyyetini ve hükmünü ve ahvâlini beyân eder. İkinci bâb, duhânın âfât ve belâlarını beyân eder. Üçüncü bâb, dahânın içmesini tevbe edip terk edenlere fâide ve menfa'atlerini beyân eder. Hakk Te'âlâ'dan niyâz ederim ki; rızasına muvafik eyleyüp okuyan ve dinleyenlere ve işitenlere te'sîrini halk edip cümlesini islâh ve bu risâleyi insanlar indinde makbul eyleyüp kullara sebeb-i irşâd eyleye. Âmîn. Bi-hurmet-i seyyidi'l-mürselîn.

3a-Evvelki bâb; muteber kitaplarda olan muteber ulemâlların duhân hakkında yirmi türlü kelâmları beyân ve ahvâlini zikreder. Evvelki kelâm, duhân habistir, her bir habîs haram olmakla duhân dahî haramdır demişler. (Ve yuharrimu aleyhimu'l-habâ'ise ${ }^{28}$ ). Hak Te'âlâ'nın kavl-i şerifinden içun yanî Rasûl aleyhi'ssalavâtu ve's-selâm kavilleri üzerine her bir habisleri harâm eder. Berîka'da ${ }^{29}$

\footnotetext{
${ }^{28}$ Araf, 7/157. Pis şeyleri haram k1lar.

29 el-Berîkatü'l-Mahmûdiyye fî serhi't-Tarîkati'l-Muhammediyye ve's-serî'ati'n-nebeviyye fi's-sîreti'l-Ahmediyye. Ebû Sa'îd el-Hâdimî (ö.1176/1762)'nin en meşhur eseri olup Birgivî Mehmed Efendi (ö.981/1573)'nin et-Tarîkatü'l-Muhammediyye fí beyâni's-sîreti'l-Aḥmediyye adlı eserinin mufassal bir şerhidir. Birgivî’nin bu eseri Kur'ân ve Sünnete uygun bir dini
} 
mezkûrdur. Ve dahi bu duhân-1 habîs olduğuna şüphe yoktur. Ve habislerin büyüğü olduğuna benim dahi şüphem yoktur. Zira duhânı içen insan yanımda bulunsa lâşe kokusundan ziyade müte'ezzî olurum. Ve her bir tabât-1 selîme olan insanların dahi böyledir. Ve dahi duhân, habîs olmasına insanların âdeti şâhittir. Ol âdet budur ki; memişhânelerde ve helâlarda isti'mâl edip bundan gayri bir şey isti'mâl etmezler. Bu âdet, duhânın bütün habislerden ziyâde habîs olmasına şâhittir. Bu âdeti kimse inkar edemez. Ve dahi sâlih ve takvâ kimseler duhânı isti'mâl etmeleri belki duhânı içenlere râzı olup buğz etmeleri dahi duhanın fenâ.... Ve habîs olmasına dahi şâhittir. Bu habis duhânı terk ve tevbe lazımdır.

İkinci kelâm; duhânı isti'mâl etmek isrâf olmakla haramdır demişler. Zirâ fâidesiz yerde akçeyi harrîc ve telef etmektir, Vesîle'de ${ }^{30}$ mezkûrdur.

Üçüncü kelam, duhânı isti'mâl etmekte ezâ olmakla harâmdır demişler. Allahu Te'âlâ'nın (ve yeselûneke ani'l-mahîzi kul hüve ezen fa'tazelû'n-nisâ'e fî'lmahîzi) ${ }^{31}$, kavl-i şerifinden için ya'nî hayız halinde hatununa cimâ' etmekde ezy olduğundan için cimâ' harâm oldu. Bu ezânın büyüğü bu habîs duhândadır. Ve bu duhânın ezâsını kimse inkâr edemez. Emir böyle olduysa duhân içmekte müminlere ve mekleklere ezâetmek mukarrerdir. Bunun için duhân haramdır demişler. (Küllü mu'zin fî̀n-Nâr ${ }^{32}$ hadîs-i şerifinden için yani haksız yerde her bir ezâ ediciler cehennemedir. Bu habîs duhândan tevbe vacip ve lâzımdır. Zirâ hadîs-i şerifte 4-aküllü kelimesi her ezâ ediciye şâmil olur.

Dördüncü kelâm, Duhân nârdan cüz’ ve kat'adır. Nâr harâm olmakla duhân dahi haramdır demişler zirâ cüz'ü olan dahi haram olur ve dahi nârın haram olması “İnnellezine ye'kulûne evvâle'l-yetâmâ zulmen; innemâ ye'kulûne fî̀ butûnihim nârâ"33 kavl-i şerifinden için Mâlikî İmamlarından rivâyet ederek Vesile'de mezkûrdur. Ve ateş haram olduğundan için ateş ile yânan şeyi yemek haram olur demişler meselâ ateş ile yansa yemesi haram olur. Yâ bu habîs duhan ki, ateşin cüzü ve aynı olarak ve azab bundan şedid olmasıyla beraber haram olduğuna şüphe kalmaz aklı olan isti'mâl etmez zira içmesine deveam ve musır olmakla gece ve

hayatın esaslarını belirtmek ve sonradan ortaya çıkan bidatlara karşı uyarı mahiyetinde telif edilmiştir.

30 Hac1 Receb b. Ahmed el-Âmidî, el-Vesîletü'l-Ahmediyye ve'z-żerî'atü's-sermediyye fî şerhi't-Tarîkati'l-Muhammediyye.

${ }_{31}$ Bakara, 2/222. Sana "adet görme durumundan" soruyorlar. De ki: "O bir rahatsızlıktır." Adet hali bitinceye kadar kadınlara yaklaşmayın.

32 Ebû'l-Fazl Celâleddin Abdurrahman b. Ebî Bekr Suyûti (ö.911/1505), el-Câmiu's-Sağı̂r C.1-2/395, No:90732, "Her eziyet veren cehennemdedir".

33 Nisa, 4/10. "Yetimlerin mallarını haksız yere yiyenler, ancak karınlarında ateş yemiş olurlar. Yakında onlar alevli bir ateşe gireceklerdir".

Turkish Academic Research Review - Türk Akademik Araştırmalar Dergisi 
gündüz ağzından düşürmemek ile kebâ'ir günâh olur. "Lâ sağîra ma'a'l-1srâr"34 hadîs-i şerifi ile kebâ'ir günahdır. Mevlâ islâh eyleye.

Beşinci kelâm, duhânı isti'mâl etmek, ya la'ib ya hehv bâ'is olmakla haramdır demişler. Zirâ bunların herbirlerin haram olması âyet ve hadîs-i şerîfler ile sabittir. Bu duhânın bunlardan olmasına şüphe yoktur. Zira duhânın şer'an aslâ fâide yoktur. Bil ki, zararı çoktur. Mecâlis-i Rûmiye'de mezkûrdur.

Altıncı kelâm duhân sekir olmakla "Küllü müskirin haramun" hadîs-i şerifi ile ve İmâm Muhammed'in "Küllü müskirin kalîluhu ve kesîruhu harâmun” kavliyle duhân haramdır. Demişler zira duhânı ibtidasında isti'mâline başlayan bâşı deverân eder. Lakin her insan böyle olmsa yine cincinden i’tibar olup bir insanın bulunması usûl-i kâ'idesi üzere kifâyet eder. Hâdimî' de ${ }^{35}$ mezkûrdur.

Yedinci Kelâm, duhanı isti'mâl etmek Allahu Te'âlâ'nın ibadetinden te'hire ve men'a sebep olmkakla haramdır demişler. "yâ eyyühellezîne Âmenû Ya eyyuhellezine amenu la tulhikum emvalukum ve la evladukum an zikrillah, ve men yef'al zalike fe ulaike humul hasirun" ${ }^{36}$ kavl-i şerifinden için demişler. Yani mâllarınız ve evlatlarınınz sizi Allahu Te’âlâ'nın zikrinden ve ibadetinden tehir ve men’ etmesin. Ya müminler bu duhânı isti'mâl eden insan namazı -4a- cemâat ile kılmaya ve namazı vaktinde kılmaya ve Kur'ân ve zikir ve salavât-ı şerife okumaya sebep olması her insanın ma'lûmudur. Böyle duhânı terk ve tevbe lazımdır. Mevlâ 1slâh eyleye.

Sekizinci Kelâm, duhanı isti'mâl etmek dalâlet ve fenâ olan bit'atlerden olmkala haramdır. Demişler şerh-i Hâdimî’de mezkûrdur.

Dokuzuncu Kelâm, misvâk-1 şerifin meşrû'iyet hikmet ve faidesini izâle ve yok etmek ile büyük kabahattir ve habâistendir. Zira misvâk-1 şerifin meşruiyeti insanın tabiatıyla ağzından peydâ olan râyiha ve kokuyu izale ve yok etmek ile ağzını temiz kılmakta peygamberlerin sünnet-i şerifi olan misvâk-1 şerîfe muhalif ve zıd olarak insan kendini dinlemesiyle kokusu necasetten habîs ve geriye olan duhanı isti'mâl edip ağzını necis gibi kokutmak insanlığa yakışır şeylerden değildir. Belki isti'mâli haramdır. Geçmişte zikrolunduğu gibi Mevlâ tevbeler ihsân eyleye.

\footnotetext{
34 lâ sagîrate ma'a-l-isrâr ve lâ kebîrate ma'a-l-istigfâr" "Israrla ve devamlı işlenen küçük günahlar (artık) küçük günah değildir; tevbe edilen büyük günah ise affolunur."

35 Ebû Sa'îd el-Hâdimî ( ö.1176/1762). Osmanlı fakihi ve mutasavvif. "el-Berîkatü'lMahmûdiyye fì Serhi't-Tarîkati'l-Muhammediyye ve's-Serî'ati'n-Nebeviyye fi's-Sîreti'lAhmediyye". En meşhur eseridir. Bu eser, İmam Birgivî'nin eț-Tarîkatü'l-Muhammediyye fî beyâni's-sîreti'l-Ahmediyye 'sinin mufassal bir şerhidir.

36 Münâfıkun, 63/9; Ey iman edenler! Mallarınız ve çocuklarınız, sizi, Allah'ı anmaktan/Allah'ın zikri olan Kur'an'dan alıkoymasın! Böyle bir şey yapanlar, hüsrana uğramışların ta kendileridir.
} 
Onuncu Kelâm, duhân insanlara azab altı olmakla isti'mâl haramdır demişler. Zira Yunus aleyhisselamın kavmine Allahu Te’âlâ duhân ile azab eyledi. Hak Teâlâ'nın 'Lemmâ âmenû keşefnâ anhum azâbe'-1 hızyi fî'l hayati'd-dunya ve metta'nahum ila hîn"37. Kavl-i şerifinden hiz-yi azâbından murda duhân azabıdır. Ve kıyamette yakın kıyamet alametlerinden yer yüzüne duhan zuhur edip kafirler azap olsa gerektir. Azâba alet olan şeyi isti'mâl haramdır demişler. Vesile'de mezkûrdur.

On birinci Kelâm, duhânı istimâl etmek haram olan kibri peyda eder. Bunun için isti'mâl haramdır demişler. Berîka'da mezkûrdur.

On ikinci Kelâm, duhânı isti'mâl etmek cehennemde muazzeb olanlara teşbih ve benzemek olmakla haramdır demişler. Rûhu'l-Beyân Tefsirinde $\dot{I} z \hat{a}$ Vaka'at suresinde beyân olduğu gibi malûm ola ki, demirden ve kalaydan ve tunçtan yüzük isti'mâl etmeden peygamberimiz nehy ve men' etti. Zira cehennem ahalisi isti'mallerine benzemekolduğundan için halbu ki duhânda bunlara benzemek -5bgyet ziyadedir. Zirâ duhân içen insanın ağzından ve burnundan cehennemde yanan kâfirler gibi duhân çıkar. Bundan gayri bun duhanda nice belâlar vardır. Mümine layık şey olmadığından tevbe lazımdır.

On üçüncü Kelâm, duhânın zifiri necâset-i galiza olmakla insanın ağzı dirhemden ziyade olup bedenin haricinde olmakla zifiri ile tükrük karışıp ağzı necis olup namazı sahih olmaz. Âlim-i fâzıl merhum Akdağı, duhân hakkında risâlesinde böyle beyân etmişdir.

On dördüncü Kelâm, duhânı isti'mâl etmek kâfirlerin tarikat ve âdet-i habîselerini ihyâ edip ve şöhret buldurup sünnet-i Rasûl aleyhissalavâtu ve's-selâm öldürmektir. Bu dahi ümmetliğe yakışıyor şeylerden olmayıp belki haramdır. Kerâhet tahrimiyle böyle duhânı terk ve tevbe lazımdır.

On beşinci Kelâm, duhânı isti'mâl edenin ağzı ve bıyıkları ve sakalı ve elbiseleri ve cemî'-i bedeni gayet kerih ve fenâ ve kabîh koku ile telbîs edip câmi'i şerîflere ve şer'an makbul meclislere giremez. Zirâ Rasûlumüz aleyhissâlâtu ve’sselâm, "men ekele min hâzihî’ş-şecerati'l-müntineti felâ yakrubanna mescidenâ" ya'nî şu kokusu kerih olan şecerden hangi kimse yerse mescitlerimize elbette yakın olmasın. Ve çiğ sarımsak ve soğan yiyen kimse câmi’i şeriflere elbette yakın olmasın. Zira bunların kokusundan melekler müte'ezzî olur. Deyû buyurmuştur. Hâlbuki bunlarda insana faide ve hevâ-yı tebdil edip sıhhata sebep iken rayihasından

37 Yûnus 10/98. Yunus'un toplumundan başka, herhangi bir ülke halkının da inanıp, inançlarının kendilerine fayda vermesi gerekmez miydi? Yunus'un toplumu inanınca dünya hayatındaki azabı onlardan kaldırdık ve bir süreye kadar onları refah içinde yaşattık.

Turkish Academic Research Review - Türk Akademik Araştırmalar Dergisi 
için nehy ve men' oldu. Bundan için fukahâ efendiler çiğ soğan ve sarımsak yemeğe ruhsat vermediler. İllâ âher memlekete giderse havasına tahvil için ruhsat verdiler. Bu hadislerden için fukahâu'd-dîn, râyihası girye olan şeyler ki çiğ pruhsa ve turp ve lahm ve balık ve yara ve sâir fenâ ve girye kokulu şeyler hangi insanda bulunsa bu kimse şer'an câmi'i şerîfe giremez deyû buyurmuşlar Berîka'da mezkûrdur. Emr böyle olduysa bu zamanda ayakkabıları başıyla necis gibi râyihası olarak gelmesi haram olan -6a- kâfirlerin kunduralarıyla câmi'i şerîfe girmek câiz olmaz. Râyiha-i kerihesinden için ve İmâm Müslim'in rivâyetiyle Peygamberimiz aleyhissalâtu ve'sselâmın vaktinde bir kimse de çiğ soğan râyihası bunmuş olmakla Rasûl aleyssalâtu ve's-selâm bu kimseyi Medine'nin hisarında dışarısı bakî'a çıkarın deyû emr buyurdu. Bunun için ulemâ buyurdular ki, bir kimse sarımsak ve soğan ve bunların misullû kokusu fena olan şeyleri yerse câmi'i şerife giderse ayağından çekilip çıkarmak lazımdır. Bu zamanda duhânı içenleri dahi câmi’i şerîflerden çekip çıkarmak lazımdır. Zira râyihası kerih olduğundan Vesîle'de mezkûrdur. Ey gâfil ve ey mağrur insan bunların insana faidesi ve gıdası olurken râyihası kerih olmakla bu misullu hükümler olmuştur. Ya bu adı ve tadı râyihası ve rengi habîs olan duhânı saatte iki üç def'a isti'mâl eden insanın hali ne şekil olur hesap eyle. İnsâf edip $\operatorname{duh}^{\wedge}$ nı terk ve tevbe ile Mevlâ akıllar ihsân eyleye âmin.

On altıncı Kelâm, Duhân Şeytanın sidiğindan halk olunmuş demişler. Bu surette aslı ve vasfı habîs olmakla isti’mâli caiz değildir.

On yedinci Kelâm, duhân insanın bedenine zarar olmakla bedeni harâp eder demişler. Barîka'da ve Mecâlis-i Rûmiye'de mezkûrdur. Böyle bedene zara olan şeyi içmek haramdır. Zira beden ibâdet alanıdır. Ve toprak mubâh iken bedene zaraı olmakla yemesi haramdır. Tabipler ve hekimlerin reislerinden İbn-i Sinâ dedi ki; eger duhân ve tuz ve fenâ koku insanın beynine girmese insan bin sene mu'ammer olurdu. Lâkin insana zaradır. Bunun için ekseri duhân içenlerin vücütları maraları ve göğüsleri balgam ile dolu, mideleri zayıf ve benizleri sarı; yemekten ve içmekten kalmış akılları idrâk etmez.

On sekizinci Kelâm, duhânın hükmü, şer’ân şüpheli olan şeylerdendir. -6aZira hakında ulemâlar beyninde ihtilaf olundu. Bunun için duhân haramdır. "Men vaka'a fi'ş-şübühşâti vaka'a fî'l-haram" ${ }^{38}$ hadîs-i şerifinden için yani şüpheli şeyi işleyen haramı işlemiş olur. Duhân gibi zira bu kelâmlar duhanın şüpheden gayri belki haramı ifade ederler. Buyle duhândan tevbe lazımdır.

\footnotetext{
${ }^{38} \mathrm{Kim}$ Şüpheye düşerse o kişi harama girer.
} 
On dokuzuncu Kelâm, eger duhânın içmesi mubâh olmsa yine şişmdiki tarik üzere isti'mâl haram olur. Zira nice türlü haramlara sebep olur. Mesela, duhân içmekte isrâf ve kibir ve ezy ve yalan ve istihzâ ve gıybet vesâir haramlar misullû aşağıda gelecektir inşâallah Te'âlâ usûl-i kâidesine mebni müsebbipler için sebepe dahi büsebbibden olan hükm verilir.

Yirminci Kelâm, duhân içilmesi sultân tarafindan bir vakit nehy ve men' olundu. Zira duhânda mâlı telef etmek vardır. Ve ulemâlar hakkında ihtilâf ettiklerinden için halbu ki, sultânın emrî şer'a muhâlif olmadıkça emrine imtisâl vaciptir. Ve sultânın vefatıyla emri nesh olunmaz demişler. Ve bu hakir dahi der ki: Duhânı içmek Rasûl aleyhi's-salavâtu ve's-selâmın kavliyle ve fiil-i yakîniyle meşhur ve memdûh olan güzel kokular, sünnet-i şerîfenin hikmet ve fâidesini izâle ve yok etmek ile peygambere ziyade muhalefet etmiş ya akıllı insan peygamber aleyhi's-selelâm cemî' güzel ve râyihaların atyabı iken yine güzel yağlar ile yağlanır idi. Yâ gâfil insan yağlanmayıp tabiat ile sende hasıl olan râyihaları izâle etmeyip bunun zıddı kerîh ve habîs râyia-i duhân ile bütün bedenini mülevves necis gibi kokmak gayet ziyâde hamâkatliktendir. Ve insâniyete yakışır şeylerden değildir. Mevlâ Teâlâ islâh eyleye. Âmin.

Ve dahi bu zikrolan kelâmların hulâsası bunlardır: Duhân habistir ve isrâftır ve ezy etmektir. Ve âteştir ve oyundur ve müskerdir. Ve ibadetten te'hîre sebeptir. Ve dalâlet olan bid'attir. Ve misvâkın meşrû'iyetini izâledir. Ve azâb etmek alâtıdır. Ve kibirdir ve cehennemde yanan mahlûklara benzemektir. Ve zifîrî necistir. Ve kâfirlerin tarikat- 6a- ve âdât-1 habislerini ihya etketir. Ve Rasûl-i aleyhi's-salavâtu ve's-selâma ve ashâbına ve evliyalara ve müçtehitlere ve sâlihlere muhâlefet etmektir. Ve insanın kerîh ve fenâ koku peydâ etmektir. Ve şeytânın sidiğinden halk olan şeyi isti'mâl etmektir. Ve şüpheli şeyi işlemiktir. Ve insanın bedenini harap eden şeydir. Ve nîce türlü haramlara sebe olan şeydir. Ve sultân tarafindan men' olan şeyi işlemektir. Ve güzel yağlar ile ve kokular ile kokulanmak hikmet-i fâidesini yok etketir. Ulemâlar bunların her birilerini delilleriyle ispât ve beyân ettiler. Bunların delilleri birer birer ihtimâli ve zannî ifade ederse yine cümlesi birden kuvvet bulup, kat'â duhânın harâm olmasını ifade ederler. İş̧bu merkezde olduysa duhânı ekmek ve biçmek ve satmak ve almak ve akçesini yemek câiz değildir.

Bunları böyle bildikten sonra duhânı terk ve tevbe vacip ve lazımdır. Ve dahî bundan sonra ma'lûm ola ki bu dahânın şer'an hükmü ve kerâhet-1 tahrîmiyle mekruh olmaklıktır. Zira beyân olan deliller zanı ifâde ederler lakin bu dahânı isti'mâl edenler gece gündüz âş̧ikâre sâatte bir iki def'a musır tarikiyle isti'mâlleri

Turkish Academic Research Review - Türk Akademik Araştırmalar Dergisi 
bu duhân kerâhati büyüyüp kebâir günah oldu. Zira aleyhi's-salâtu ve's-selâm, Lâ sağîrata ma'a'l-1srâr" kavl-i şerifinden için yani küçük günhı daima işlemek ile büyük günah olur. Bu dahâna isrâriyet olduğu cümlenin ma'lûmudur. Bu duhânda nice âfatlar ve belâlar olmakla ve nice haramlara sebep olmakla harâm olur. İkinci bâbda inşâallah âfatları beyân olacaktır. Ve bundan evvel yirmi türlü kelâmları hulâsasından ma'lûm olmuştur. Her halde bunu terk ve tevbe lâzımdır. Hak olan budur.

İkinci Bâb: Duhân âfat ve belâlarını, maraz ve zararlarını beyân eder. İsmâil Hakkı (kaddese sırrahu), İzâ vaka'at suresinde "ve zıll-i men yahmûm" deyu beyân etmiştir. Lâkin bu hakîrullah Te'âlanın inayetiyle duhânın afatlarının bir miktarını 6b- beyân eder ki: Her kişi anlayıp duhânı terk ve tevbe etsin. Duhanın âfatlarından bulduğumuz âfatları kırküç âfâttır.

Evvelki Peygamberimiz aleyhi's-sâlâtu ve's-selâma ve babasına ve anasına eza etmiş olur. Zira pazarertesi ve Perşembe günü ameller Allahu Te'âlâ'ya ve babasına ve anasına arzolunur. Eger ameli hayır ise mesrur olurlar. Ve eger ameli şer ise müteezzî olurlar. Atfâlu'l-müslimîn hakkında İmâm Birgivî'nin Risâle'sinde hadîs-i şerîf ile beyân etmiştir.

İkinci fâidesiz şey de mâl ve akçe telef etmektir. Bu dahi ahmak ve sefihlere benzemek. Bu da câiz değildir. Ve sefihliktir.

Üçüncü, kâfirlere ve ahmak ve sefihlere benzemiş bu da câiz değildir.

Dördüncü, içenin kalbi perk ve katı olup Hakkı anlamaz ve kabul etmez.

Beşinci, insanı âhirette helâk eder zirâ kalbin olması helâke sebep olur.

Altınc1, meleklere ve duhânı içmeyenlere ezâ etmiş olur.

Yedinci, ağzı ve sakalı ve bütün cesedi kerih ve gayet kabîh kuku ile mülevves etmiş olur.

Sekizinci, duhânı isti'mâl edenden Allah razI olmaz. Zira nefsine tâbi' olup, şer'an kerih ve habis şey işlediğinden için.

Dokuzuncu, nefsin hevâsina tâbi’ ve nefsine esir ve hâdim olmakla bütün helâkine sebep olur. Zira nefsine tâbi’ olmakla helâk âşikâredir.

Onuncu, Peygamber ve ashaplarına ve evliyâlara ve ulemâlara ve Salihlere muhâlefet etmiş olur. Böyle şey Mümine lâyık değildir.

On birinci, duhân insanlara dünyada sıklet, âhirette pişmanlık verir. Zira duhân sebebiyle kalbi fenâ olup, gafletlere batmış olduğu için. 
On ikinci, âhirette hesabı çok uzun olur. Zira çok mal telef etmek hes3abın çok olmasını icâp eder.

On üçüncü, âhirette niçin bu duhânı isti'mâl ettin deyû unuf ve menhâ ile sûâl olur.

On dördüncü, âhirette azabı icâp zira isyânın bulunup tevbesiz öldüğünden için tebve ile ya insan gafleti ter ile

On beşinci, duhânı isti'mâlden insana Allahu Te'âlâ ve Rasûu ve sâlih kimseler buğz edip sevmezler. Ma’siyete musır ve daim oldukları için -7b-

On altıncı, duhân, isti'mâl eden insanlardan Allahu Te'âlâ i’râz eder. Allahu Te'âlâ bu kimseye rahmet nazarıyla bakmayıp ibâdetini ve du'âbsını kabul etmez. Zira mâlâ ya'ni ile meşgul olduğundan için. Sallallahu Teâlâ aleyhi ve sellem. “Alâmet-i i'râzulluhi Te’âlâ ani'l-abdi, iştigâlehû bi-mâlâ ya'nihı̂” yani Allahu Te'âlâ kuldun i'raz edip dusaını ve ibâdetini kabul etmemek alameti ve nişânı kul şer’an muksûdu olmayan şey ile meşgul olmaklığıdır. İmdi bu duhân ile meşgul olmak şer'an makûd olmayan şey ile meşgul olduğu cümlenin ma'lûmudur. Emr böyle olduysa duhân içenlerin ibâdeti ve duâsı kabul olmaz. Allahu Te’âlâ bundan i'râz ettiğinden için. Bu hadîs-i şerifinde çok hisse vardır. Tefgekkür lazımdir.

On yedinci, Duhân içmek fâsık ve sefihler ile görüşmeğe sebep olur. Halbu ki bunlara buğz edip sevmemek lazımdır. Zira insan dünyada hangi kimseye muhabbbet ederse âhirette onun ile olsa gerektir. "el-Mer'u ma'a men ahab" hadîs-i şerifinden yani insan dünyada hangi kimseye muhabbet edip muvâfakat ederse âhirette bunun ile haşrolur.

On sekizinci, Duhân içen insan çok hayırlı amellerden geri kalmağa sebep olur. Meselâ cemâ'ata eremez. Yahut hiç gidemez. Duhân ile meşgul olmak sebebiyle husûsan sabah nazainda Mevlâ islâh eyleye.

On dokuzuncu, Duhân içen insan fena huylar peyda edip çok günahlara sebep olur meselâ duhân içmek kendine tabiat olan insan duhânı tabâtına muvafık bulmaz ise yahut çubuğu hazır olmamış olsa bu kimse gazaplanıp sureti gazaplanmış kelp suretine benzeyerek söver. Belki gazabından nâşî küfre sebep olan kelâmı söyleyip kâfur olmasına sebep olur. Husûsan Ramazan-ı Şerîfte duhân belâsından nice âfatlar işler. Biri budur ki; uyku ile vakitleri geçirip farz olan namazları hiç kılmaz ve bu eşeklerde akıl da hiç kalmaz. -8a- Bu ekseri duhân habisindendir. Kimsenin aklı idrâk etmez Allah 1slâh eyleye. Bundan böyle hr kimse bulduğu kendi

Turkish Academic Research Review - Türk Akademik Araştırmalar Dergisi https://dergipark.org.tr/tr/pub/tarr 
belasıdır. Kimseye bahane bulmayıp ancak kendi nefsine bahane ki bunların ekseri bu duhandan 39

Yirmi yedinci, Duhân içmekte vakitleri ömürleri zayî’ etmek vardır. Ve bu dahi büyük musibettir. "Azamu'l-musîbete tazyî'i'l-evkât"40 hadîs-i şerifinden için yani musibetlerin büyüğü faidesiz yerde ömürleri zayi’ etmetir. Bu duhan ve nargile ile meşgul olan vakitleri zâyi’ etmiş olduğu âş̧ikardır.

Yirmi sekizinci Duhânı isti'mâl etmek şer'an menhî ve haram ve mezmûm olan yerlerde oturmaya sebep olur. Mesela kahvehanede zira kahvehanânede şer'an oturması ve girmesi haram ve mezmûm olanlaın en ziyade haram ve fenasıdır. Zira kahvehâne rezil ve sefih ve ahmak ve battallar ve tenbeller yeridir. Ve gâyet ziyade çok büyük günahlar mahallidir. Zira kahvehânede yalan ve nemmamlık ve istihzâ ve türlü oyunlar ve kahkaha ile gülmek ve gelen geçen hatunlara imretlere bakmak ve fâsıklara muhabbet edip beraber olmak ve gafillere muhabbet ile kendi gafil olmak Mevlâyı ve ahireti unutmak ve cemâ'at vakti gelip gaflet ile cemâata gitmemek ve giybet etmek ve hemzedip insanlara ta'n ve iftira etmek ve bu kahvehaneye gitmeği ma'siyet ve günah bilmemek ve kahvehaneye gitmeğe tevbe etmemek ve bu onüç günah kahvehanede mevcuttur. "Veylün li-külli hümeze"41 kavl-i şerifinden olup belki ziyade olarak günahkâr olur yani insanları ta'n ve gıybet ve istihzâ eden her insan içindir. Büyük azbaplarım Hak Te'âlâ buyurdu; imdi böyle kahvehânede zarûretsiz oturmak meyhâne ve karhâneden eşettir. Zira meyhânede ve kârhânede birer günah işlenir. Ve günah haram olduğunu bilirler ve tevbe ederler. Lâkin hibîs kahvehanede tevbe dahi etmezler. Herhâlde bu kahvehaneye zarûretsiz girmeği tevbe ve farz lazımdır. Zira bir kere gitmekte on üç büyük günah işlemiş olur. Ne'ûzu billah böyle kahvehânede oturmak ve su şerbet içmek haramdır. Zira açık ma'siyetlerin ve günahların bir olduğu için böyle kahvehanenin akçe ve kirası ve kisbi dahi habis ve hararmdır. Haramlara sebep olduğu için imdi duhân içen kimse böyle mahall-i habise oturmasına sebep olur bu miktar günahları işlemiş olur. Duhânın tevbesi dahi vaciptir. Ve İsmail Niyazî buyurdu ki meyhaneye ve raks ve dönmek ve çalgı olan tekkelere ve kahvehanelere zaruret için giren insan sol ayakla girmelidir. Bundan hisse alasız.

Yirmi dokuzuncu, Duhan içmete olan bir günahı âşikâra olmakla iki günah olur. Zira o günah gizli olursa bir günah olur, âşikâre günah olursa iki günah olur.

\footnotetext{
39 8b-9a varakları fotoğrafta tamamen kapanmış ve okunamamaktadır.

40 Zamanın boșa harcanması en büyük musibettir.

${ }^{41}$ Hümeze, 104/1 Arkadan çekiştiren, ayıp kusur arayan.
} 
Otuzuncu, Duhânı içen kimselerden bir kimse vefât edip kabre konulduk da sel gelip kabristanı alırken bu kimsenin kabrini dahi alıp cenazesini götürecek korkusundan selâmet-i kabre koyalım diyerek kabrini açıp görsünler ki, zekerini eliyle ağzına koymuş yatur. İnsanlar cem olup böyle görüncek bu kimsenin halini hatunundan sual edip cevabında benim ehlimde duhandan gayrı bir şey yok idi. Ulemâlar dedirler ki, bu rezillik duhan çubuğunun cezasıdır. Beyan ettiler. Bütün icmâlî Barîka'da mezkûrdur. Ve bazı duhan içenlerin kabri duhân ile dolup sonra zayi’ olup havaya kalkmıştır. Bunlardan gayri alametler salih kimselerin rüyalarıyla malum olmuştur. Barîka'da mezkûrdur. Bu duhânı içende akıl yoktur.

Otuz birinci, Duhânı içmek imansız ölmeğe sebep olur. Zira imansız ölmenin sebeplerinden bir ezâ etmek duhandan çok ezâlar vardır geçmişte. Büyük ve küçük günahlara dalmak malum olmuştur. Ve İsmail Hakkı, Hadîs-i Erbaîn'in altıncı hadis-i şerhinde buyurdu ki; bir zarar ki ehl-i fitrata râci' ola, sair mazarrattan akçadır. Şürb 8b- duhan gibidir. Tabiat sâniye olup iştigâl-ibadete mü'eddî olur. Bu ise, ya kâfirdir yahut küfre karîb nesnedir. Ve ibn Abdisselâm Kitâbu'l-Vesâ'il'de demiştir şarap el-hamr, âsî; eklü’l-haşiş olana kâfir denilir. Hakkının kelamı nihayet buldu.

Bu hakir der ki, şarabı haram diyerek içen kimse kâfir olmaz, belki âsî ve fâsık olup cehenneme müstahak olur. Lâkin haşiş yani haram olan esrar ve afyon gibi şeyleri mübâh diyerek yiyen kimseye kâfir denilir. Abdusselâm'ın murâdı budur. Bu duhânı içen kimse ibâdete üşenip ve ibâdet kendine ağır olur. Ve nice türlü günahlara ve gafletlere sebep olmakla imansız olmasına sebep olacağı derkâr ve âşikârdır. Lakin akıllar idrâk etmez oldu.

Otuz ikinci, Duhân içmek, misvâk-1 şerifin faidesini izâle edip, yok etmektir.

Otuz üçüncü, Duhân güzel kokuların faidesini yok etmektir.

Otuz dördüncü, Duhân, insanın bedenine zararı olmakla âfat-1 batındır. Yani karnına haramdan ve mekruhtan koyduğu şeylerden azâb olacak şeylerdendir.

Otuz beşinci, Duhân içen kimsenin bedeni zayıf olup ibâdete neşâtı olmaz. Bu veçhile istimâli haramdır.

Otuz altıncı, Duhân isti'mâl olan yerde âşikâra Kur'ân ve zikir ve tespih ve salat-1 şerîf okumak caiz değildir. Zira duhânın râyihası necasetten kerih ve kabihtir. Fukahâ efendilerimiz kerîh râyiha olan yerde âşikâre ta'zîme muhalif olduğundan câiz değildir. Dediler eğer, okursa günahkâr olur. Bu zamanda mektepler ve 
medreseler ve tekkeler ve evler ve odalar duhân habîsinin rayihasıyla necis gibi kerîh kokusu olup âşikâra okuyup günahkâr olurlar. Ve Mushaf-ı Şerîf ve hadîs ve tefsir-i şerifi ve fikh-1 şerîf kitapları duhân habîsinden sahipleri olan ulemâların ilmi gitmiş câhiller gibi olmuş belki dinin fesadına sebep oldu. -10a- Akıllar idrâk etmez belki duhânı zem eden ulemalara bazı adavet ederler. Mevlâ şerlerinden hıfz eyleye.

Otuz yedinci, Duhanı isti’mâl nice türlü günahlara ve belalara sebep olup haram işlemiş olur. Mesele bu duhan a'lâ ve iyi ve tayyip duhandır ve misk gibi kokusu vardır diyerek, ismi ve kokusu ve tadı gayet kerih ve habis olan duhana böyle söylemek halis haram olana haramı söyleyip büyük günah işlemiş. Lakin tabiatı habis olanlara duhan tayyip ve a'lâ olur. Haşerât böcekleri necasetten telezzüz edip hoşlanması gibi.

Otuz sekizinci, Duhân içmek, haram olan kibri peyda eder. Hususan yasemin, çubuk ve kehribâr ve takım ile içtiği vakitte kibri büyür koltukları kabarır şişer ve gözler içilir. Nice kibirler ve ucublar peyda olur. Ne'ûzu billahi Te'âlâ

Otuz dokuzuncu, Duhânı içenin bu zamanda kâfirlerin âdet-i habîseleri duhânı kâğıt içinde kâfirler heyeti ve şekli üzere duhânı içmekte ve ismini cığara demekte; dört adet bela ve musibet ziyade vardır. Evvelki şer'an ta'zimi olan kâğıtlara tahkir etmektir. İkinci, kâfirlerin âdeti isti'mâl edip tekrar ma'siyettir. Zira cığara kâfirlerin bir 1stılahıdır. İsti’m3ali caiz değildir. Dördüncü cığarı, akçesiyle kâfirleri zengin kılıp kendi fakir olmaktır. Ve dahi malûm ola ki kâfirlerin istılahlarını zarûretsiz söylemek caiz değildir. Belki ma’settir. Zira kâfirlere teşbih olduğu için mesela sıgara, familya, setre, pantol, komisyon böyle kelamları söyleyen bunları söylemeden tevbe etmek lazımdır. Mevlâ 1slah eyleye.

Kırkıncı, Duhânı kimse içenlere razı olup günahı iki kat olur. Zira masiyete buğz etmeyip razı oludğu için.

Kırk birinci, Duhânı içen kimse üşenip ibadet kendine ağır ve sekîl olmasına sebep olur. Ve ibâdeti acele ve süratle işleyip, âsim ve günahkâr oulur. Mesela namazı kılarken kırâ'atı ve tespihleri acele edip yanlış okur. Ve ta'dil-i erkânı terk eder. Ve câmi-i şerîflerde va’z ve ders dinlemeye acele edip duramaz, münafık gibi câmilerden kaçmaya sebep olur. Zira duhânı içmekten geç kaldım diyerek terâvih namazını böyle acele edip vacip ve sünneti duhân habisini tamam eder. Bu dahi insanlığa yakışmaz.

Kırk ikinci, Duhânı içenlerden ziyaret melekleri kaçar ve firâr eder. Yani ziyarete gelmeleri duhânın râyihası gerih ve habis olduğu için, 
Kırk üçüncü, Duhân isti'mâl ederek tabiat olan insana duhân-ı habîs ve mekruh ve haramdır. Duhân içer deyu men' ve nehy eden ulemaya buğz ve adâvet etmek küfürden korkulur. Bu ise bu ulemalar günah işlemesin; bu günahlardan men' ve nehy eden böyle ulemaya buğz ve adavet etmek, Alah Te'âl ya ve rusulune buğz etmek lazım gelmek ile küfür olduğuna şüphe yoktur. Bu duhân habîsi böyle fenalıklara sebep olur. Bu kelâmı dikkat ile tefekkür eyle. Dünyanın fesadını anla zira Allah Te'âlâ'nın ve Rasulunun ahkâmı olduğu gibi söyleyen buğz ve adavetten başka ya nefy edip yahut şehit ederler. Böyle eden zalim umerâlara ve zalimlere müdahane eden zalim âlimin acab İslamiyet'te var mı? Ne'ûzu billah Hak Te'âla şerlerinden cümemizi hıfz eyleye âmin.

$\mathrm{Bu}$ risâlenin muktezasıyla amel edeler. Mevlâ ameller ihsan eyleye âmin. Emir böyle oldu ise bundan böyle bu duhânı terk ve tevbe etmek vaciptir. Ya insan nefsine merhamet eyle, sağına soluna bakma kendine bak kendini islah, duhânı terk eyle. Çok hayırlara muvaffak olursun. Mevlâ cümlemizi muvaffak bi'l-hayr eyleye. Âmîn.

Ücüncü Bâb, Duhânı terk ve tevbe edenlerin fâide ve menfaatlerini beyân. Onlar dahi yirmi adettir. Evvelki, duhânın günahları mağfiret olur. Azaplardan halas olur.

İkinci, Allahu Te'âlâ ve Rasûlu bu kimseden razı olurlar.

Üçüncü, zengin olmaya sebep olur. Zira duhânı terk ile malını halas edip şükrünü bilmek ile malı çok olup kanâat üzere olur.

Dördüncü, ağzını ve sakalını ve elbiselerini ce cemî’i bedenini necis kosusundan gerih olan duhân kokusundoan temiz etmiş olur.

Beşinci, cemâtlara ve camilere ve namaz vaktinde gitmeğe sebep olur.

Altınc1, ibâdetlerini lezzetini bulmaya sebep olur

Yedinci, kalbine nûr olup Hakk ile bâtılı fark etmek ile Hakkı bulmaya sebep olur.

Sekizinci, ulemâlar, Salihler ve müminler bu duhânı tevbe edelere muhabbet edip, razı olurlar.

Dokuzuncu, âhirette hesap az ve suhuletli olur.

Onuncu, duhânı terk çok hayır ve sevaplara sebep olup ahirette zengin olmaya dahi sebep olur. Mesela duhânha verecek akçeyi ya borca ya nafakasına yahut bir hayrata ya bir fukaraya verip sevabı çok ve ahirette mansıbı a'lâ olur.

Turkish Academic Research Review - Türk Akademik Araştırmalar Dergisi https://dergipark.org.tr/tr/pub/tarr 
On birinci, Nefs-i emareye ve şeytana muhalefet etmek ile cennete tezce girip fevz ve necât bulmaya sebep olur.

On ikinci, duhânı icad eden kâfirlere ve isti'mâl edenlere ve fasıklara buğz etmiş olur.

On üçüncü, ibâdet etmeğe isteği ve neşâtı olur.

On dördüncü, ibadeti sükûnet üzere te'ennî ve yavaşça işleyip ibadeti tamam ve sevâbı çok olur.

On beşinci, gıybet ve yalanları az olmasına ve sevabı çok olmasına sebep olur.

On altınc1, kahvehâne böyle habis yerlere oturmaktan halas olur. Zira kahvehanede ve sokaklar üzerine ve ma'siyet meclislerine zarutetsiz oturmak büyük ma'siyettir. Böyle şeylerden tevbe etmek kimenin aklına gelmez oldu.

On yedinci, sefih ve ahmak kimseler ile görüşmemeğe sebep olur.

On sekizinci, takvâ ve salih kimseler ile görüşmeğe sebep olur.

On dokuzuncu, kâr ve kisp sebepleri kendine kolay ve suhûletli olur. Zira Allah Te’âlâ'dan korkup terk etmesi rızkın sebepleri ve kapıları açılır. Duhânı içen kimseye rızık sebepleri ve kapıları kapandı̆̆ı gibi.

Yirminci, duhânı terk eden kimse şeytana ve nefsine muhalefet etmek suhûletli olup, başka günahlardan halâsa dahî sebep olur. Tevbe İnşâallah halâs olursun. Bi-avnillahi Te'âlâ dahi malûm ola ki, nargile denilen şey duhân gibi bir habistir. Duhânda olan âfatlar ve zararlar nargile de mevcuttur. Nargilede üç bela ziyade vardır. Evvelki, tönbeki akçeleriyle Kızılbaşları zengin edip, bunlara benzemektir. İkinci, Allah Te’âlâ bize fazlıyla ikrâm buyurduğu tâhir ve temiz suyu necis edip, faydasız yerde israf çok etmektir. Bu dahi küfrân-1 ni’met olup yeryüzünde yağmur az yağmakla bereket az olup cemî’i mahlûklara hıyanetlik etmiş olur. Ne'ûzu billah nargileyi terk ve tevbe ile zira büyük beladır. Üçüncü, insan nargileyi içerken hınzırın sesine ve savtına müşabehe bir suret peyda olup nargile içen kimseye bir gururiyet ve kibir hasıl olup ziyade lehiv ve oyun olmasına ve .... olmasına sebep olur. Mümin kimseye layık ve yakışır şeylerden değildir. Tevbe ile mağrur olma ve gâfil fasıklara bakma zira ölüm yakındır. Ve bazı kimseler nargile Firavn'ın icadıdır dediler. Bu surette nargile içen kimse Fir'avn'a benzemiş olur. Harhalde tevbesi lazımdır. Ve dahi malûm ola ki, enfiye dedikleri şey dahi duhân-1 habîs gibidir. illâ zifîri yoktur. Lâkin enfiye de duhândan iki fenalık vardır. Evvelki, koynunda ve cebinda necisten fanâ ve kabîh bir bez taşırlar, kendi ve görenler gayet 
nefret edip iğrenirler. Ve müte'ezzî olurlar. Bununla camilere girerler ve câmi'i şerîfe ta'zîme muhâlif olmakla çok büyük belâdır. Ekseri bu zamanın gafil ulemâ ve talebelerinden böyle görünüyor bunların gafil oldurları cümlenin malumudur. Bunlara bakılamaz tevbe ile gaflet etme.

İkinci -11b-bedeni zayıf ve ibâdete noksanı olur. Bunları def' için ruhsat oldu. Ammâ duhânı tarikle insanın bedenini harap eder. Ve bu miktar afâtlar ve belâlara sebep olduğu için isti'mâl câiz değildir. Ve böyle suâl-i şeytânın hilesindendir zira eğer remz-i misk üç yüz dürt yüz yıl evvel olan ulemâlar bunları isti'mâl etmezler iken ulemaları ve amelleri ve zikirleri ve telifleri ve tasnifleri ne derece ve ziyade çok idi! Ve kemâl-i dîniyeleri dahi ziyade idi. Ya insan insaf ile bu zatların böyle kemâlde olmakları duhân ve nargile ve enfiye habislerini isti'mâl ile mi oldu? Hâşâ vallahu bunlar ile değildir. Belki bu zevâtlar yemeği ve içmeği ve uykuyu az edip; riyâzet ederek ve ibâdet lezzetini bulmak ve Allahu Te'âlâ'ya ve Rasulune muhabbet ve âş1k olmakla oldu. Zira sizin dediğiniz gibi olsa duhân ve nargile ve enfiye isti'mâl etmeyen ulemâların ilimleri ve amelleri ve ibâdetleri sizden az olmak ve sizin ilimleriniz ve amelleriniz bunlardan çok ve ziyade olmak lazım gelir. Hâlbuki siz bu zevatların teliflerini ve ibâdetlerini anlamakdan acziniz vardır. Nerede kaldı ki ilimleriniz bunlardan çok olsun. İnsâf ile şeytana muvafik Hakkı reddetme ehl-i Hakk'a dahl edip cahiller ve avamları dalalete düşürme. Mevlâ cümleyi ıslâh eyleye. Suâl olursa şimdiki vakitte bütün insalnla bunlar ile meşgul olmuşdur. Eğer bunlara fenâ deniliyorsa bütün milletimize fenâ demek lazımdır. Bunlardan sükût etmek lazımdır. Bunda iki cevâb vardır. Evvelki cevap bu suâl dünya ehline ve zalimlere müdâhane ve ilmî resmiyyede müstahtem olan ulemaların kelâmıdır. Bu kelâma bu suâle iltifat olmaz.

İkinci cevap, bütün millet duhân ve nargile ve enfiye ile müptelâ olmakları bunların fenalığını daf' etmez eger milletin ibtilâsı fenâlığı def' eder. Şimdiki zamanda insanlar için haramlar ve zulümler ve fesâtlar ve bid'atlar ve oyunlar ve çalgılar ile müptela olup mecbur olmuş -12a- böyle olmakları cümlenin malumudur. Mesela oyunlar ve çalgılar ve rüşvet veya yemek ve şarap ve rakı içmek ve ibâdullaha zulm etmek ve suretlere muhabbet edip hânelerde tutmak ve ahiret ulemasına buğz etmek ve gıybep ve bühtân ve yalan ve nemmâmlık ve namaz kılmamak ve zekât vermemek ve evlâtlar ebeveyne ve hatunlar erkeklerine; esirler seyyitlerine âsî olmak ve unvan ve nice türlü habasetler ile millet meşgul olmaklı̆ğ cümlenin malûmudur. Böyle iken milletimiz tahlis için bunlardan sükût etmek olur mu? Hâşâ sükût etmek caiz olmaz. Bu duhân ve nargile ve enfiyeden sükût câiz olmayıp, hükmünü ve mezmiyyetini ve habisliğini beyân edip cümle ümmet-i

Turkish Academic Research Review - Türk Akademik Araştırmalar Dergisi https://dergipark.org.tr/tr/pub/tarr 
Muhammedî bunlardan men' ve zecr ve nehy etmek, emr-i lâzımdır. Böyle suâl bir miktar suâla benzerdi.

Eğer bilinmez bunlardan gayrı harâm ve günahlardan içtinap edeydi. Mevlâ 1slâh eyleye. Suâl olunursa bu duhân ve nargile ve enfiyeyi ulemâlar va kadılar ve müftüler ve şeyhler ve müritler ve talebeler isti'mâl ediyorlar. Biz bunlara duhân ve nargile ve enfiyeden suâl ettiğimizde bunların zarı yoktur derler. Ve bazı ulemlar günah ve mekruh ve haramdır derler. Biz şaşıp hayerette kaldık. Efendi! Bize cevap ver. Cevap budur: bu duhân ve nargileyi ve enfiyeyi isti'mâl eden ulemaların ve şeyhlerin her birleri envâ'ı türlü ma'siyet ve fisklar ve bidatlar ve günahlar ile meşgul olup fasıklardır. Dünya muhabbetine dalmış dünyayı ve insanları harap etmektedirler. Ve firsat bulsalar nice türlü zulumlar ve rüşvetler alıp hakkı nâ-hakk edip nâ-hakk eder. Ve zalimlere ve fâsıklara müdâhane ma'siyetlere izin verip razı olurlar. Böyle oldukları cümlenin malumudur ki; dünyaya muhabbeti olmayan ve günahlardan sakınan âhiret ulemaları ve şeyhleri ve talebe ve müritler duhân ve nargile ve enfiyeyi isti'mâl etmezler. Ve isti'mâl edeneli men' ve nefy edip buğzz ederler. Ve usûl-i kâidesidir ik; takvâsı olan ulemâların kavliyle amel olur. Fâsıkların kelâmıyla amel olmaz. Ve cümlenin dahi malûmudur duhân ve nargile ve enfiye fenâ ve kabîh denilir. Takvâ ulemalardır. Böyle olduysa bunları terk ve tevbe vacip ve lazımdır. Ve dahi kahve dedikleri şeyde duhânda olan habislikler olmadığından mübâhtır. Lakin keyif ve oyun ve kahvehânede içiliyorsa haramdır. Ammâ ta'âmı hazım ve uykuyu dağıtırsa yorgun kimseye fayda olursa içilir. Lakin bu zamanda zalimler ve fâsıklar âdeti olduğu için terki evlâdır.

Va's-salâtu ve's-selâmu alâ Muhammedin ve âlihi ecma'în. Ve'lhamdulillahi Rabbi'l-âlemîn. Temme.

\section{Sonuç}

Osmanlı Devleti'nde XVI. yüzyıldan itibaren toplumun tanışmaya başladığı çeşitli mükeyyefat türü maddelerden birisi de tütün ve tütün ürünleri olduğu görülmektedir. Tedhîn, duhân ve tedhînât gibi tavsifler yapılan tütün hakkında o dönemlerde çok sayıda müstakil eser yazılmış ve zararlarından bahsedilmiştir. Bu konuda Türkiye Kütüphaneleri yazma koleksiyonlarında yer alan küçük boyutta risaleler bize konunun fikhi ve sosyal yönleriyle ele alındığını göstermektedir. $\mathrm{Bu}$ konuda yazılan eserlerin çokluğuna bakılarak bir tütün, kahve, afyon gibi mükeyyefâta dair manzum ve mensûr literatür kaleme alınmış; çeşitli fetvâ kitapları tutulmuş olduğuna şahit olmaktayız. 
Risâle fíd-Duhân olarak tesmiye edilen eser, üç ana bâb üzerinden yazılmıştır. Birinci Bâb'da müellifin her biri ayrı bir fikhî görüşünü beyan eden başlık şeklinde yazılmış toplam yirmi "Kelâm" yer almaktadır. Bu kısımda genellikle tütün ve tütün imal etmenin haram olduğuna dair ulema görüşlerine yer verilmiş ve zaman zaman da içtinaba vesile olması için abartılı istidlale başvurulmuştur.

İkinci Bâb ise müellifin ifadesiyle "Duhân âfat ve belâlarını, maraz ve zararlarını beyân eder". Bu kısımda da genel olarak tedhînin, afyon ve diğer duhân şeklinde içilebilen maddelerin zararlarını yine başlıklar ile açıklanmaya çalışılmıştır. $\mathrm{Bu}$ bâbda da toplam kırk üç madde yer almakta ve bunların her birinde farklı konularda; söz gelimi duhân, cıgara ve sıgara gibi dışarıdan ithal edilen isimler ile anıldığı için münafik alameti olarak zikredilmiştir. Üçüncü Bâb ise Duhânı terk ve tevbe edenlerin maddi ve manevi kazançlarına işaret etmek üzere yirmi madde üzerinden yazılmıştır.

Bu risalede tütün gibi ayrıca diğer bağımlılık yaptığı ifade edilen nargile ve enfiye de ulemaca terk ve tevbe edilmesi elzem maddelerden sayılmaktadır. Bunun yanı sıra yorgunluğu aldığı ve hazmı da kolaylaştırdığı için kahvenin içilmesi mübâh görülmüştür.

\section{Kaynakça}

Albayrak, Ali, “Alevi-Bektaşi Ritüelleri ve Temel Kurumlarından Hareketle Sosyal Bütünleşme", Sûfi Araştırmaları, 2015, cilt: VI, sayı: 12, s. 21-36.

Atay, Rıfat - Ciğer, Mustafa, "Bilişsel Gelişim Seviyelerine Göre İnsanın Allah'la İletişimi”, I. Uluslararası Din ve İnsan Sempozyumu "Din, Dil ve İletişim”" 10-12 Ekim 2019 Eskişehir, 2019, s. 996-1009

Ceviz, Nurettin, "Kahvenin İslâm Dünyasına Girişi ve Arap Edebiyatında Ele Alınışı", EKEV Akademi Dergisi - Sosyal Bilimler-, 2004, C.VIII, S. 18, ss. 343356.

Dilmen, Ömer, Turuk-ı Aliyyede Cihâz-ı Tarîkat, İlâhiyat Yay., Ankara 2020.

Gürsu, Orhan, Bağımlılık ve Din Nöropsikolojik Bir Yaklaşım, Dem Yay., İstanbul 2018

Turkish Academic Research Review - Türk Akademik Araştırmalar Dergisi https://dergipark.org.tr/tr/pub/tarr 
474 Osmanlı Toplumunda Tütün Bağımlılığına Karşı Bir Sosyal Sorumluluk Örneği: Risâle Fi'd-Duhân

“İnancın Bağımlılık Karşısındaki Fonksiyonu”, Sosyal

Hizmet ve Bütün Yönleriyle Bağımlılık, Ed. Y. Sinan Zavalsız, Grafiker Yay., Ankara 2020, ss.269-299.

İpşirli, Mehmet, “Atâullah Mehmed Efendi”, DİA., İstanbul 1991, C.IV/46.

İpşirli, Mehmet; Uzun, Mustafa İsmet, "Bahaî Mehmet Efendi”, DİA., İstanbul 1991, C.4/463-465.

Kalaycı, Mehmet; Öztürk, Eyüp, “18. Yüzyıl Osmanlı Coğrafyasında Tütünün Sosyo-Kültürel Zeminine Dair Bir Metin: Ebū Sehl Nu'mān Efendî ve Tahlîlu'd-Duhân Adlı Risâlesi”, Ankara Üniversitesi İlahiyat Fakültesi Dergisi 58/1, (2017), ss.1-45.

Karaismailoğlu, Adnan, “Altıparmak Mehmed Efendi”, DİA., İstanbul 1989, C.II/542.

Okur, Kâşif Hamdi, “17. Yüzyıl Osmanlı Fıkıhçılarının Nevazile Yönelik F1khî Argümantasyonu (Mehmet F1khî el-Aynî ve Risâletu'd-Duhân ve'l-Kahve Örneği)", Sahn-ı Semân'dan Dârulfünûn'a Osmanlı'da İlim ve Fikir Dünyası (Âlimler, Müesseseler ve Fikrî Eserler) - XVII.Yüzyıl, İstanbul 2017, ss. 381-393.

Özel, Ahmet, “Haskefi”, DİA., İstanbul 1997, C.16/387. , "Nablusî Abdulgani b. İsmail", Di்., İstanbul 2006, C.32/268-270.

Özen, Şükrü, “Tütün”, DİA., İstanbul 2012, C.42/5.

Saylan, Şenol, “17. Yüzyıl Osmanlısında Bir Tütün Müdafaası: Ahmed Devletî’nin Risâletü'l-İnsâniyye fî Bahsi'd-Duhâniyye, Adlı Risâlesi”, Abant İzzet Baysal Üniversitesi Illahiyat Fakültesi Dergisi Dergiabant: Abant İzzet Baysal Üniversitesi Illahiyat Fakültesi Dergisi, 2020, C. 8, Say1. 1, s. 27-57.

Şahin, Osman “Risâle fî̀ Hükmi’t-Tütün ve'l-Kahve li-Muhammed F1khî elAynî el-Hanefî Emînü'l-Fetvâ (Dirâse ve Tahkîk)", İslam Hukuku Araştırmaları Dergisi, 2018, say1: 31, ss. 697-714.

Tosun, Musa, "Bağımlılık ve arka Planında Yer Alan Sebepler", Sosyal Hizmet ve Bütün Yönleriyle Băglmlılık, Ed. Y. Sinan Zavalsız, Grafiker yayınları, Ankara 2020.

Ünal, Vehbi, “Sosyal Bir Sorun Olarak alkol/Madde Ve Teknoloji/Dijital Bağımlılı̆̆ı”, Sosyal Sorunlarda Güncel Tartışmalar, Ed. Yılmaz Daşlı, Ankara 2019, ss. 269-278.

Turkish Academic Research Review - Türk Akademik Araştırmalar Dergisi 
Yayla, Mustafa, "Hadimî Ebû Said", DİA., İstanbul 1997, C.15/24-26.

Yılmaz, Ayşegül, Kitap Tanıtımı/Review, "es-Sulh Beyne'l-İhvân fî Hükmi İbâhati'd-Duhân, Abdülganî b. İsmâil en-Nablusî (tahkik: Muhammed Edîb elCâdir), Dımaşk, 2015, 240 sayfa”. Abant İzzet Baysal Üniversitesi İlahiyat Fakültesi Dergisi, Bahar 2019, C.7, S:13, s.337-340.

Turkish Academic Research Review - Türk Akademik Araştırmalar Dergisi https://dergipark.org.tr/tr/pub/tarr 
476 Osmanlı Toplumunda Tütün Bağımlılığına Karşı Bir Sosyal Sorumluluk Örneği: Risâle Fi'd-Duhân

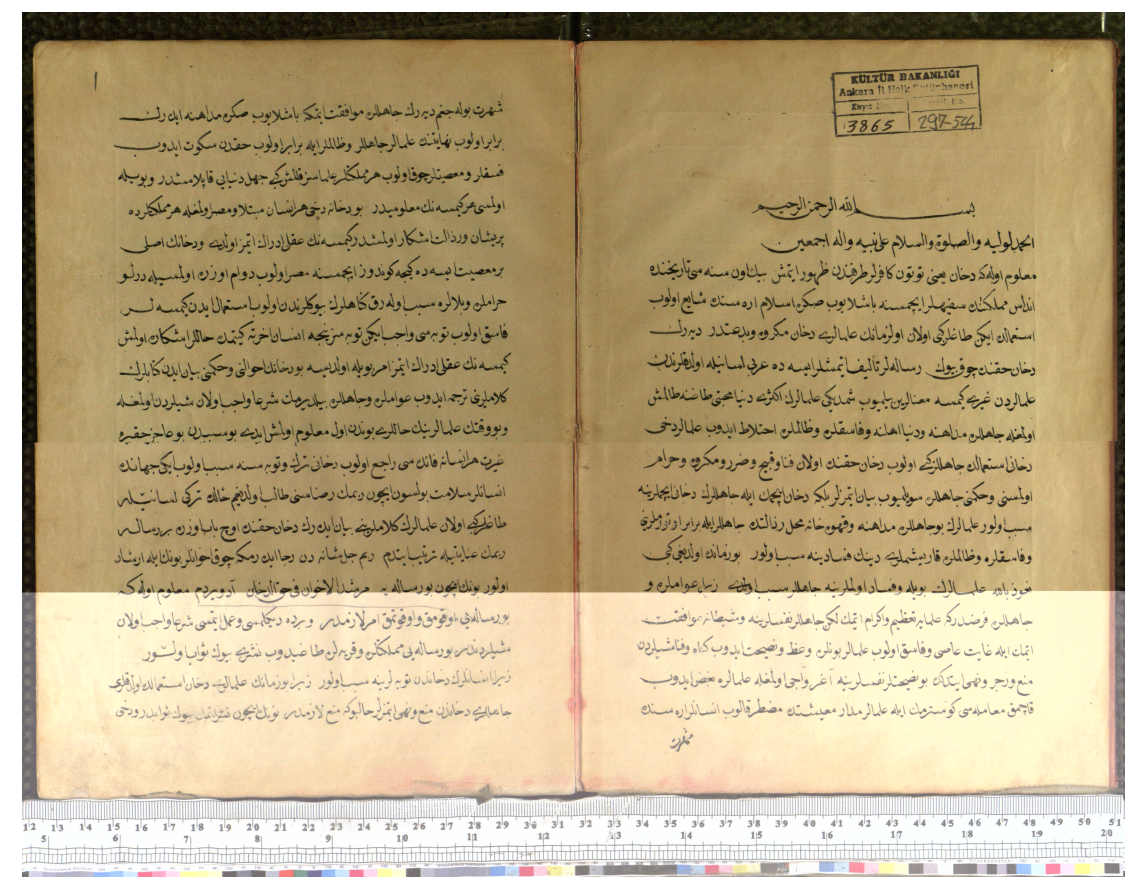

Turkish Academic Research Review - Türk Akademik Araştırmalar Dergisi 